A N N A L E S

UNIVERSITATIS MARIAE CURIE-SKŁODOW S A

LUBLIN - POLONIA

VOL. LXXVI

SECTIO F

2021

Biuro Badań Historycznych. Instytut Pamięci Narodowej Oddział w Lublinie

\title{
SŁAWOMIR POLESZAK
}

ORCID: http://orcid.org/ 0000-0003-3857-9938

slawomir.poleszak@ipn.gov.pl

\section{Podziemie niepodległościowe w Polsce w latach 1947-1953. Próba syntezy}

The Independence Underground in Poland between 1947 and 1953: An Attempt at Synthesis

\begin{abstract}
ABSTRAKT
Po przeprowadzonej wiosną 1947 roku akcji ujawnienia struktur polskiego podziemia niepodległościowego ludzie, którzy pozostali w konspiracji, nie stanowili już dla władzy komunistycznej żadnego poważnego zagrożenia. Postanowili kontynuować dalszą walkę, gdyż nie wierzyli komunistom, nie godzili się na sowietyzację Polski i liczyli na szybki wybuch trzeciej wojny światowej. Struktury podziemnych organizacji wojskowych zostały rozbite do przełomu 1949/1950 roku. Do końca 1953 roku zlikwidowano ostatnie grupy lokalne i oddziały zbrojne. Pozostały jedynie kilkuosobowe grupy zbrojne o charakterze ,przetrwaniowym”.
\end{abstract}

Słowa kluczowe: polskie podziemie niepodległościowe; podziemne organizacje wojskowe; oddziały zbrojne; władza komunistyczna; konspiracja

\section{WSTĘP}

W ostatnich latach historycy opublikowali kilkaset artykułów i książek opartych na źródłach, a poświęconych poszczególnym organizacjom konspiracyjnym, oddziałom leśnym czy poszczególnym konspiratorom. Jeśli nie liczyć zbiorowego dzieła, jakim jest Atlas polskiego podziemia niepodległościowego 1944-1956 ${ }^{1}$,

1 Atlas polskiego podziemia niepodleglościowego 1944-1956, red. S. Poleszak, R. Wnuk, A. Jaczyńska, M. Śladecka, Warszawa-Lublin 2020. 
to nikt nie podjął próby syntetycznego opracowania dziejów antykomunistycznego podziemia działającego w latach 1947-1953. W moim przekonaniu istniejące już prace szczegółowe pozwalają na wypełnienie tej luki.

Przez „podziemie niepodległościowe” rozumiem wszystkie „dorosłe” organizacje podziemne oraz oddziały zbrojne, pomijam zatem funkcjonowanie młodzieżowych organizacji konspiracyjnych ${ }^{2}$, a także grup i organizacji zamieszkujących Polskę mniejszości narodowych. Przyjęte ramy chronologiczne wyznacza stanowiąca punkt zwrotny amnestia z wiosny 1947 roku. Po jej zakończeniu w podziemiu pozostali ludzie najbardziej zdeterminowani, niewierzący w deklaracje komunistycznej władzy oraz liczący na to, że opór ma sens, gdyż nieuchronny jest wybuch konfliktu między światem Zachodu i Wschodu. Cezurą zamykającą jest rok 1953, kiedy to rozbite zostały ostatnie organizacje lokalne i większe grupy zbrojne. W „lesie” pozostało kilkanaście kilkuosobowych grup o charakterze ,przetrwaniowym”, które zostały rozbite na przestrzeni kolejnych dwóch lat. Efekt przyjęcia powyższych założeń powoduje, że poza moim polem zainteresowania znalazło się polskie podziemie działające na obszarach Drugiej Rzeczypospolitej, które na skutek postanowień teherańsko-jałtańskich znalazły się poza granicami ,ludowej” Polski.

\section{UJAWNIAĆ SIĘ CZY ZOSTAĆ W PODZIEMIU?}

W dniu 22 lutego 1947 roku wyłoniony miesiąc wcześniej w wyniku sfałszowanych przez komunistów wyborów parlamentarnych Sejm Ustawodawczy uchwalił ustawę o amnestii ${ }^{3}$. Głównym inicjatorem przeprowadzenia akcji ujawnienia było Ministerstwo Bezpieczeństwa Publicznego. Dzięki niej planowano osiągnąć dwa cele zasadnicze. Po pierwsze, doprowadzić do pogłębienia dezintegracji i kryzysu w szeregach podziemia poprzez nakłonienie jak najszerszego grona konspiratorów do zaprzestania działalności podziemnej. Po drugie, nie mniej ważnym zadaniem było zewidencjonowanie środowiska wrogiego wobec władzy komunistycznej. Doświadczenia zebrane w trakcie amnestii przeprowadzonej latem 1945 roku$^{4}$ oraz tzw. dzikich amnestii z lata 1946 roku - skierowane wobec konspiratorów Związku Zbrojnej Konspiracji w Radomskiem oraz członków Ruchu Oporu Armii Krajowej (ROAK) w Pułtuskiem i Narodowego

2 Zob. J.W. Wołoszyn, Zapomniane ogniwo. Konspiracja młodzieżowa na ziemiach polskich 1944-56, Warszawa 2019.

3 Ustawa z dnia 22 lutego 1947 r. o amnestii (Dz.U. 1947, nr 20, poz. 78).

4 T. Łabuszewski, Amnestia 1945 r i Deklaracja Jana Mazurkiewicza ,Radostawa”, [w:] Komunistyczne amnestie lat 1945-1947 - drogi do „legalizacji” czy zagłady, red. W.J. Muszyński, Warszawa 2012, s. 130 i n. 
Zjednoczenia Wojskowego (NZW) na Kurpiach - pokazywały, że amnestia może być skutecznym sposobem zwalczania struktur podziemia niepodległościowego. Ogłoszenie „dzikich” amnestii poprzedzały dobrze przygotowane operacje policyjno-wojskowe. $\mathrm{W}$ ich wyniku zostało aresztowanych wielu konspiratorów, m.in. dowódca Związku Zbrojnej Konspiracji por. Franciszek Jaskulski „Zagończyk” oraz inspektor ROAK por. Stanisław Rożek „Przebój”. Prowadziło to do dezintegracji miejscowego podziemia i do zniechęcenia do dalszej walki. Wtedy miejscowe władze Urzędu Bezpieczeństwa (UB) wychodziły z inicjatywą pozbawionej oparcia w jakimkolwiek akcie prawnym lokalnej amnestii ${ }^{5}$.

Na przełomie 1946 i 1947 roku pogłębiała się decentralizacja podziemia. Od wiosny 1946 roku Komenda Główna NZW istniała tylko nominalnie, nie miała więc realnego wpływu na „,teren”. Konspiracja narodowa wówczas to szereg niezależnie funkcjonujących struktur obszarowych i okręgowych ${ }^{6}$. W noc sylwestrową z 1946 na 1947 rok aresztowano niemal cały sztab II Komendy Konspiracyjnego Wojska Polskiego na czele z por. Jerzym Jasińskim „Januszem”7 Na początku stycznia 1947 roku rozbity został III Zarząd Główny (ZG) Zrzeszenia „Wolność i Niezawisłość” (WiN), kierowany przez ppłk. Wincentego Kwiecińskiego „V-T”, którego ujęto 5 stycznia 1947 roku wraz z jego pierwszym zastępcą do spraw polityczno-wychowawczych Kazimierzem Czarnockim „X-2” (co najmniej od sierpnia 1946 roku współpracownikiem UB, współodpowiedzialnym na rozbicie III ZG WiN). Dzień wcześniej zatrzymano drugiego zastępcę Kwiecińskiego, odpowiedzialnego za sprawy wojskowe ppłk. Stanisława Sędziaka „S-2”8. Straty ponosiły również okręgi, a ubytki kadrowe coraz trudniej było uzupełnić. Konspiratorzy działający w podziemiu nieprzerwanie od kilku lat byli zdekonspirowani na swoim terenie, co wymuszało dowodzenie „na odległość”. Najlepszym przykładem był Okręg WiN Lublin, gdzie dowództwo komendy okręgu i inspektoratów przebywało na stałe w Warszawie i kierowało konspiracją poprzez przesyłanie rozkazów i wytycznych za pośrednictwem łączników9

5 K. Krajewski, nie można złamać podziemia, należy je rozłożyć. „Dzikie” amnestie na terenie województwa warszawskiego (1945-1946), [w:] Komunistyczne amnestie..., s. 282 i n.; R. Śmietanka-Kruszelnicki, „Dzikie” amnestie na przykładzie Zwiąku Zbrojnej Konspiracji na ziemi radomskiej (sierpień-wrzesień 1946 r.) Inspiracje i konsekwencje [w:] Komunistyczne amnestie..., s. 303 i n.

6 M. Bechta, W.J. Muszyński, Przeciwko pax sovietica. Narodowe Zjednoczenie Wojskowe i struktury polityczne ruchu narodowego wobec reżimu komunistycznego 1944-1956, Warszawa 2017, s. 182-184.

7 T. Toborek, Stanisław Sojczyński i Konspiracyjne Wojsko Polskie, Łódź 2015, s. 183.

8 T. Łabuszewski, Komenda Obszaru Centralnego ,Nie”-DSZ-WiN, ,,31 ”, ,Zatoka”, ,,Wista”, [w:] Obszar Centralny Zrzeszenia WiN 1945-1947, red. T. Łabuszewski, Warszawa 2018, s. 191 i n.

9 R. Wnuk, Lubelski Okręg AK DSZ i WiN 1944-1947, Warszawa 2000, s. 60. 
Nieprzerwanie prowadzone operacje wojskowe przez jednostki Korpusu Bezpieczeństwa Wewnętrznego (KBW) zmuszały dowódców dużych oddziałów partyzanckich (szczególnie zgrupowań) do dzielenia ich na mniejsze pododdziały. Nękanie stałym pościgiem powodowało konieczność ciągłej zmiany miejsca pobytu, a więc przemierzanie w ciągu doby co najmniej kilkunastokilometrowej, nużącej (szczególnie późną jesienią i zimą) marszruty. Ciągła styczność bojowa ze ścigającą grupą operacyjną oraz kolejne starcia i potyczki, w których oddział tracił żołnierzy (byli zabici, ranni czy wzięci do niewoli), powodowały narastanie stresu i zniechęcenie oraz osłabiały wiarę w zwycięstwo (w lutym 1947 roku poległ m.in. mjr Józef Kuraś „Ogień”, legendarny dowódca partyzancki na Podhalu). Brak snu, odpoczynku i niejednokrotnie problemy z aprowizacją i ciepłymi ubraniami czy też brak możliwości zmiany bielizny potęgowały zmęczenie.

Czynnikiem niezmiernie ważnym również z psychologicznego punktu widzenia było sfałszowanie wyborów parlamentarnych z 19 stycznia 1947 roku oraz brak reakcji ze strony państw demokracji zachodnich. Gdy podziemie niepodległościowe znajdowało się w głębokiej defensywie, komuniści wyszli z ofertą skorzystania z możliwości ujawnienia się. Funkcjonariusze Ministerstwa Bezpieczeństwa Publicznego (MBP) starali się nie popełniać wcześniejszych błędów i optymalnie przygotować przeprowadzenie tej operacji. W tym celu rozsyłano do lokalnych kierownictw UB okólniki, w których próbowano wyjaśnić dokładnie: kto podlegał amnestii, w jaki sposób powinna zostać przeprowadzona operacja na danym terenie oraz w jaki sposób wykorzystywać sieć agenturalną do pogłębiania niepewności i dezintegracji w szeregach podziemia, a tym samym skłonić jak największą liczbę konspiratorów do opuszczenia podziemnych szeregów ${ }^{10}$.

Jednym z najpoważniejszych problemów, przed jakim stanęli funkcjonariusze UB, było przezwyciężenie dużej nieufności członków podziemia, których nurtowało pytanie o prawdziwe intencje władzy komunistycznej oraz nie wierzyli w to, że ujawnienie się będzie gwarantować im spokojne życie. Nieufność wynikała chociażby z działań podjętych w stosunku do osób ujawnionych latem i jesienią 1945 roku. W celu choć częściowego zminimalizowania tej nieufności władze MBP postanowiły zwolnić pewną liczbę aresztowanych, co miało być dowodem na jej dobre intencje. Głównym zadaniem opuszczających więzienia miało być jednak uczestnictwo w akcji popierania amnestii oraz aktywny udział

${ }^{10}$ L. Pietrzak, Amnestia 1947 roku i jej wykonanie przez organa bezpieczeństwa [w:] Podziemie zbrojne na Lubelszczyźnie wobec dwóch totalitaryzmów 1939-1956, red. S. Poleszak, A. Puławski, Warszawa 2002, s. 61. 
w przekonywaniu i skłanianiu do ujawnienia niedawnych swoich współtowarzyszy czy podkomendnych ${ }^{11}$.

Należy zgodzić się ze stwierdzeniem Mariusza Mazura, że o ile wyjście z konspiracji w 1945 roku służyło temu, by wrócić do cywilnego życia i pracy, o tyle ujawnienie się wiosną 1947 roku było ratowaniem się przed śmiercią ${ }^{12}$.

Oficjalnego stanowiska w sprawie amnestii nie zajęło kierownictwo krajowe Zrzeszenia WiN. Tym samym z problemem tym musiały sobie poradzić dowództwa okręgowe WiN. O ile w okręgu lubelskim WiN zapanowała zgoda co do konieczności ujawnienia, o tyle w okręgu białostockim doszło do ostrego kryzysu. Przeciwko legalizacji na warunkach komunistów wystąpili prezes rejonu białostocko-sokólskiego kpt. Franciszek Potyrała „Oracz” i dowódca oddziału samoobrony Obwodu WiN Wysokie Mazowieckie kpt. Kazimierz Kamieński „Huzar”, którzy na bazie dotychczasowych struktur WiN planowali stworzyć kadrową organizację konspiracyjną pn. „Wolność i Sprawiedliwość”. Sytuacja była bardzo napięta, gdyż „Oracz” wydał wyroki śmierci na członków komendy okręgu, którzy opowiadali się za ujawnieniem. Ostatecznie to on został zastrzelony z 3 na 4 kwietnia 1947 roku z rozkazu ostatniego prezesa okręgu białostockiego, kpt. Józefa Ochmana „Ligonia”13. Wyroki śmierci na kilku członkach organizacji, którzy się ujawnili, wykonano z rozkazu dowódcy III Komendy Konspiracyjnego Wojska Polskiego (KWP) sierż. Jana Małolepszego „Murata”"14. Do rozłamu doszło również w Komendzie Okręgu NZW Białystok. Zdecydowanym przeciwnikiem zakończenia pracy konspiracyjnej był komendant tego ogniwa, płk Władysław Żwański „Błękit”. Zwolennicy wyjścia z konspiracji skupili się wokół jego zastępcy - kpt. Bolesława Kozłowskiego „Grota”. Wydane przez płk. „Błękita” rozkazy zakazujące ujawnienia pod groźbą kary śmierci nie powstrzymały około 2 tys. członków (około $50 \%$ stanów) przed wyjściem z konspiracji ${ }^{15}$. W wielu przypadkach dowódcy

11 P. Gasztold-Seń, Problemy Ministerstwa Bezpieczeństwa Publicznego w przygotowaniu i realizacji amnestii 1945 i 1947 r., [w:] Komunistyczne amnestie..., s. 67-73.

12 M. Mazur, Antykomunistycznego podziemia portret zbiorowy 1945-1956. Aspekty mentalno-psychologiczne, Warszawa-Lublin 2019, s. 384.

13 K. Litwiejko, Franciszek Potyrała (1897-1947), [w:] Słownik biograficzny, t. 1: Konspiracja i opór społeczny w Polsce 1944-1956, red. J. Kurtyka, Kraków-Warszawa-Wrocław 2002, s. 373374; K. Krajewski, T. Łabuszewski, Zagadka śmierci Franciszka Potyrały „, Oracza”, „Zeszyty Historyczne WiN-u" 2008, nr 28-29, s. 62-71.

14 T. Toborek, op. cit., s. 193.

15 S. Poleszak, Podziemie antykomunistyczne w Łomżyńskiem i Grajewskiem (1944-1957), Warszawa 2004, s. 327-328; M. Bechta, W.J. Muszyński, op. cit., s. 278-282. 
oddziałów byli zmuszeni podejmować samodzielne decyzje w sprawie ujawnienia siebie i swoich podkomendnych ${ }^{16}$.

W sumie na terenie kraju ujawniło się 53317 osób, z czego 25755 jako członkowie organizacji, 7750 jako członkowie „band” (oddziały partyzanckie) oraz 19812 jako „dezerterzy Ludowego Wojska Polskiego (LWP), KBW, Milicji Obywatelskiej (MO), UB, Ochotniczej Rezerwy Milicji Obywatelskiej (ORMO) i Służby Ochrony Kolei (SOK)". Amnestia objęła też 23257 osób przebywających w więzieniach, spośród których zwolniono 20548 osób, a 2709 osobom zmniejszono wysokość kary więzienia. $\mathrm{Z}$ amnestii skorzystało zatem łącznie 76574 osoby ${ }^{17}$. Jeśli spojrzymy na liczbę ujawnionych w poszczególnych regionach kraju, to uwagę zwracają szczególnie dwa województwa: lubelskie, gdzie w sumie ujawniło się 11970 osób (4359 jako członkowie organizacji podziemnych, w tym 3777 członków WiN), oraz białostockie, gdzie ujawniło się 10128 osób (9434 jako członkowie organizacji podziemnych, w tym 6051 członków WiN, 436 Narodowych Sił Zbrojnych [NSZ] i 1892 NZW) ${ }^{18}$. Kolejne miejsce, jeśli chodzi o liczbę osób ujawnionych, zajęło województwo warszawskie - 6498 osób (2670 jako członkowie organizacji podziemnych, w tym 919 członków WiN $)^{19}$. Z szacunków poczynionych przez funkcjonariuszy UB wynika, że np. na terenie województwa białostockiego ujawniło się $90 \%$ członków WiN i około $50 \%$ NZW.

Akcja ujawnienia przeprowadzona wiosną 1947 roku nie zniszczyła podziemia niepodległościowego całkowicie, ale zadała mu olbrzymi cios.

\section{STRUKTURY CENTRALNE - IV ZARZĄD GŁÓWNY ZRZESZENIA „WOLNOŚĆ I NIEZAWISŁOŚĆ”}

Akcja ujawnienia przeprowadzona w marcu i kwietniu 1947 roku spowodowała rewolucyjne zmiany. Zniknęły dwa największe związki konspiracyjne na poziomie okręgowym WiN: białostocki i lubelski. W konspiracji pozostał IV ZG WiN. Udało się to, gdyż stojący na jego czele prezes ppłk Łukasz Ciepliński

16 Z. Broński „Uskok”, Pamiętnik (wrzesień 1939 - maj 1949), wstęp i red. S. Poleszak, LublinWarszawa 2015, s. 226; M. Surdej, Amnestie i akcja ujawnieniowa na Rzeszowszczyźnie w latach 1945-1956, [w:] Komunistyczne amnestie..., s. 250-251.

17 IPN BU, 0397/79, Dane liczbowe o osobach objętych amnestiami w latach 1945, 1947, 1952, Ministerstwo Spraw Wewnętrznych, Biuro „C”, Warszawa 1972, k. 0008pdf; Protokół z odprawy szefów WUBP, 28 IV 1947 r., [w:] Aparat bezpieczeństwa w latach 1944-1956. Taktyka, strategia metody działania, cz. 1: Lata 1945-1947, oprac. A. Paczkowski, Warszawa 1994, s. 102.

18 IPN BU, op. cit., k. 0011pdf, 0017pdf.

19 Ibidem. 
„Bogdan”, nie chcąc dopuścić do ujawnienia podległej mu organizacji oraz obawiając się, że może to spowodować aresztowanie kierownictwa, zakazał ujawnienia osobom, które miały cokolwiek wspólnego z dowództwem organizacji ${ }^{20}$. Tym samym udało się zachować stan posiadania obejmujący jedynie teren Obszaru Południowego (okręgi: Rzeszów, Kraków, Górny Śląsk i Wrocław).

Już na początku grudnia 1946 roku zaczął się kształtować IV Zarząd WiN. Na jednej z odpraw ówczesnego prezesa Obszaru Południowego WiN ppłk. Łukasza Cieplińskiego „Bogdana” z najbliższymi jego współpracownikami: mjr. Adamem Lazarowiczem „Wojnarem”, kpt. Franciszkiem Błażejem „Poleskim”, „Karolem”, mjr. Mieczysławem Kawalcem „Izą” oraz kpt. Ludwikiem Kubikiem „Alfredem”, „Juliuszem”, zadecydowano o przekształceniu dowództwa obszarowego w kierownictwo krajowe $\mathrm{WiN}^{21}$. W tym czasie nominalnie istniał jeszcze III ZG WiN kierowany przez ppłk. Wincentego Kwiecińskiego „V-T”. Jednak ujęcie go przez UB na początku stycznia 1947 roku rozwiązało spór kompetencyjny między nimi oraz spowodowało, że jedynym ośrodkiem mającym możliwość dalszego kierowania pracami WiN była grupa oficerów Obszaru Południowego skupionych wokół ppłk. Cieplińskiego ${ }^{22}$. Członkowie ścisłego kierownictwa IV ZG WiN oraz dowództwa struktur terenowych wywodzili się z szeregów konspiracji rzeszowskiej.

Po zakończeniu akcji ujawnienia struktura terenowa Zrzeszenia WiN zasadniczo ograniczała się do Obszaru Południowego, w skład którego wchodziły okręgi: Katowice (Górnośląski), Kraków, Rzeszów i Wrocław. Po objęciu stanowiska prezesa głównego przez ppłk. Cieplińskiego na stanowisku prezesa obszaru zastąpił go kpt. Franciszek Błażej „Poleski”, „Bogusław”. Poszczególnymi okręgami dowodzili: Katowice - ppłk Stefan Rutkowski „Haszysz” (listopad 1946 - 21 września 1947), Kraków - Józefa Petriczek „Wilejka” (styczeń - 22 października 1947), Rzeszów - kpt. Władysław Koba „Tor” (4 maja - 26 września

20 Z. Zblewski, Okręg Krakowski Zrzeszenia „Wolność i Niezawistość” 1945-1948. Geneza, struktury, działalność, Kraków 2005, s. 522.

21 Ibidem, s. 469; idem, Próba aktywowania Obszaru Zachodniego przez IV Zarząd WiN, [w:] Obszar Zachodni Zrzeszenia WiN 1945, red. K. Krajewski, Warszawa 2019, s. 254.

22 Podział funkcji w sztabie zarządu wyglądał następująco: prezes ppłk Łukasz Ciepliński „Ostrowski” (styczeń - 27 listopada 1947); p.o. prezesa mjr Mieczysław Kawalec „Iza” (listopad 1947 - 1 lutego 1948); zastępca prezesa mjr Adam Lazarowicz „Wojnar” (do 5 grudnia 1947); sekretarz Stefan Sieńko „Wiktor”; Wydział Informacji i Propagandy mjr Mieczysław Kawalec „Iza”; Wydział Organizacyjny i Łączności kpt. Ludwik Kubik „Alfred”, „Juliusz” (do 9 grudnia 1947); Stefan Sieńko „Wiktor” (do stycznia 1948); łączność zewnętrzna Józef Szmid „Łucja”, „Szymon”; łączność wewnętrzna Józef Batory „Wojtek”, „August”; łącznik na PSL Karol Chmiel „Leon”; dział polityczny Józef Rzepka „Znicz”, „Krzysztof”. Na podstawie: http://zhwin.pl/zrzeszenie-win/cztery-zg-win-u/iv-zarzad [dostęp: 4.05.2021]. 
1947), Wrocław - mjr Ludwik Marszałek „Zbroja” (styczeń-grudzień 1947)23. W okresie poamnestyjnej działalności liczba wszystkich członków organizacji oscylowała wokół kilkuset. Okręgiem najliczniejszym i prowadzącym najbardziej prężną działalność był okręg rzeszowski ${ }^{24}$.

Na przełomie 1946 i 1947 roku, czyli w trakcie zawiązania się IV Zarządu WiN, położenie organizacji ulegało zasadniczej zmianie. O ile dla Zrzeszenia kierowanego przez ppłk. Franciszka Niepokólczyckiego „Teodora” najważniejszym zadaniem było niedopuszczenie do sfałszowania przez komunistów wyborów parlamentarnych oraz dopomożenie ugrupowaniom niepodległościowym i opozycyjnym w ich wygraniu, o tyle dla ppłk. Cieplińskiego i jego najbliższych współpracowników nie ulegało wątpliwości, że komuniści uczynią to skutecznie, tak jak pół roku wcześniej w przypadku tzw. referendum ludowego. W związku z tym stanęli przed wyzwaniem opracowania koncepcji, która nadawałaby dalszy sens istnieniu organizacji oraz wskazywałaby, za pomocą jakich form działania można by ją realizować. Obserwacja i analiza sytuacji międzynarodowej skłoniła ich do wniosku, że możliwy jest szybki wybuch trzeciej wojny światowej między Wschodem a Zachodem. To w niej upatrywali nadziei na zmianę położenia Polski i na koniec sowieckiej dominacji ${ }^{25}$.

Założenia przyjęte przez kierownictwo IV Zarządu prowadziły do zintensyfikowania współpracy ze służbami specjalnymi/wywiadowczymi państw zachodnich, w tym przede wszystkim Stanów Zjednoczonych. Głównym wymiarem tej współpracy miało być prowadzenie intensywnych działań wywiadowczych na obszarze Polski, a następnie przekazywanie zebranych informacji wywiadom państw anglosaskich. Mogły być one przydatne w momencie planowania czy rozpoczęcia działań wojennych ${ }^{26}$. Zrzeszenie WiN miało być swoistym reprezentantem polskiego społeczeństwa wobec mocarstw zachodnich, ze szczególnym uwzględnieniem roli Stanów Zjednoczonych. Do września 1947 roku

23 Na podstawie: T. Balbus, O Polskę Wolna i Niezawista (1945-1948). WiN w poludniowo-zachodniej Polsce (geneza - struktury - działalność - likwidacja - represje), Kraków-Wrocław 2004, s. 327 i n., 459-465; idem, Zrzeszenie WiN na Dolnym i Górnym Śląsku (struktury okręgowe), „Zeszyty Historyczne WiN-u” 2002, nr 17, s. 124-131; Z.K. Wójcik, Władysław Antoni Koba (1914-1949), [w:] Stownik biograficzny, t. 4: Konspiracja i opór społeczny w Polsce 1944-1956, red. M. Bielak, K. Krajewski, Kraków-Warszawa-Wrocław 2010, s. 284; Z. Zblewski, Okręg Krakowski..., s. 471, 568; A. Dziuba, Podziemie poakowskie w województwie śląsko-dąbrowskim w latach 1945-1947, Kraków 2005, s. 168, 170.

24 Z. Woźniczka, Zrzeszenie „Wolność i Niezawistość” 1945-1952, Warszawa 1992, s. 98; Z. Zblewski, IV Zarząd Główny Zrzeszenia „Wolność i Niezawistość”, „Wyklęci. Ogólnopolski kwartalnik poświęcony Żołnierzom Wyklętym” 2018, nr 1(9), s. 41.

25 Z. Zblewski, Próba aktywowania..., s. 254-255.

26 Ibidem, s. 255. 
przedstawiciele IV Zarządu utrzymywali kontakty z ambasadą USA w Warszawie. W czerwcu tego roku tą drogą przekazano memoriał skierowany do Departamentu Stanu USA, który prawdopodobnie dotarł do adresata. W liczącym kilkanaście stron dokumencie zawarto szczegółową analizę aktualnej sytuacji międzynarodowej oraz złożono propozycję współpracy ${ }^{27}$.

Zdając sobie sprawę z potrzeby dostarczania wywiadom anglosaskim jak najszerszego zasobu informacji, kierownictwo WiN widziało potrzebę objęcia strukturą organizacyjną obszarów położonych na zachodzie i północy kraju. Dlatego też pojawiła się wizja odbudowy Obszaru Zachodniego WiN. W kwietniu 1947 roku istniał on, ograniczając się jedynie do Okręgu WiN Wrocław. Dowodził nim mjr Ludwik Marszałek „Michał”, „Zbroja”28. Według planów oficerów IV Zarządu struktury okręgowe miały zostać zorganizowane w Bydgoszczy, Gdańsku, Poznaniu i Szczecinie. Pozwalała na to sytuacja finansowa organizacji, która uległa poprawie za sprawą Delegatury Zagranicznej WiN kryptonim „Dardanele", która zaczęła zasilać organizację krajową środkami finansowymi. Komórkami okręgowymi mieli dowodzić działacze z terenu Obszaru Południowego WiN. Oprócz zadań ściśle organizacyjnych komórki WiN na terenie Obszaru Zachodniego WiN miały być azylem dla zdekonspirowanych i ściganych działaczy zaangażowanych w pracę podziemną w ramach Obszaru Południowego WiN ${ }^{29}$.

$\mathrm{Na}$ stanowisko prezesa Obszaru Zachodniego WiN mianowany został mjr Adam Lazarowicz „Wojnar”, najbliższy współpracownik ppłk. Cieplińskiego. Ostatecznie wysiłki mjr. Lazarowicza zakończyły się niepowodzeniem, a głównej tego przyczyny należy upatrywać w pogłębiających się problemach kadrowych. Wynikały one albo ze zniechęcenia do dalszego konspirowania, albo ze „słabości materiału" typowanego do objęcia stanowisk kierowniczych ${ }^{30}$. Pomimo tych trudności ppłk. Ciepliński nie zrezygnował z realizacji tego zamysłu. We wrześniu 1947 roku mianował na stanowisko kierownika Okręgu Gdańsk WiN

27 Memoriat Zrzeszenia WiN do Departamentu Stanu USA z 15 czerwca 1947 r. w sprawie nawiązania wspótpracy politycznej, oprac. A. Waligóra-Zblewski, Z. Zblewski, „Zeszyty Historyczne WiN-u" 1999, nr 12, s. 151-163. Ze szczegółową treścią sprawozdań przesyłanych przez IV ZG WiN w 1947 roku można się zapoznać w tomie dokumentów: Zrzeszenie ,Wolność i Niezawisłość” w dokumentach, luty-listopad 1947, red. J. Huchlowa, M. Huchla, t. 3, Wrocław 1997.

28 T. Balbus, Major „Zbroja”, Wrocław 2013, s. 110-121.

29 Z. Zblewski, Próba aktywowania..., s. 256-257. Na temat prób reaktywacji okręgu gdańskiego (pomorskiego) zob. M. Szymaniak, Zrzeszenie WiN w województwie gdańskim (1945-1947), [w:] Obszar Zachodni..., s. 183-186.

30 Z. Woźniczka, op. cit., s. 98; Z. Zblewski, Próba aktywowania..., s. 257; Z.K. Wójcik, Adam Lazarowicz (1902-1951), [w:] Stownik biograficzny, t. 2: Konspiracja i opór społeczny w Polsce 1944 -1956, red. W. Frazik, Kraków-Warszawa-Wrocław 2004, s. 290-291. 
ppłk. Wincentego Stefana Rutkowskiego „Bolesława”, który przestał pełnić funkcję kierownika Okręgu Górnośląskiego (Katowickiego). Wywodził się on również z konspiracji rzeszowskiej i podobnie jak ppłk. Lazarowicz nie mógł się pochwalić znaczącymi osiągnięciami. Co więcej, już na początku listopada 1947 roku zgodnie z rozkazami ppłk. Cieplińskiego musiał przerwać wykonywanie zadania w związku z nasilonymi aresztowaniami prowadzonymi przez $\mathrm{UB}^{31}$. W maju 1947 roku podjęto próbę zorganizowania na nowo Obszaru Centralnego WiN (województwa: białostockie, lubelskie, łódzkie, olsztyńskie, pomorskie, warszawskie). Misję jego reaktywacji ppłk Ciepliński powierzył mjr. Józefowi Rządzkiemu „Cezaremu”. Nie było mowy, aby podejmować próbę odbudowy struktur konspiracyjnych, chodziło jedynie o stworzenie ośrodka dowódczego, który przede wszystkim skupiłby się na kierowaniu pracą działających na tym obszarze siatek wywiadowczych. Udało się to jedynie w stopniu minimalnym, gdyż do reaktywowanego „sztabu” weszły obok „Cezarego” jedynie dwie osoby ${ }^{32}$.

Wraz z upływającym czasem kierownictwo IV Zarządu WiN uświadamiało sobie, że rządy komunistyczne w Polsce potrwają zdecydowanie dłużej, niż wcześniej zakładano. Dlatego też zastanawiano się nad działaniami ukierunkowanymi na grupy które w przyszłości będą w naturalny sposób elitą społeczeństwa, kadrami dla WiN bądź nośnikiem idei Zrzeszenia. Wobec powyższego postanowiono zaktywizować zabiegi uświadamiające środowisko akademickie. Planowano to czynić poprzez dostarczanie prasy winowskiej czy referatów materiałowych, w których poruszano różne zagadnienia. Zamierzano w ten sposób utrwalić postawy niepodległościowe oraz zminimalizować wpływ propagandy komunistycznej. Ich prowadzenie rozpoczęto w czerwcu 1947 roku $^{33}$. Przeszkodą trudną do przezwyciężenia były jednak narastające problemy związane z drukiem. Kolejnym środowiskiem, które próbowano infiltrować i na nie oddziaływać, była Polska Partia Socjalistyczna (PPS). Po sfałszowanych wyborach do Sejmu oraz po rozbiciu Polskiego Stronnictwa Ludowego (PSL) uważano, że poprzez wpływanie na PPS uda się powstrzymać objęcie całkowitej władzy przez Polską Partię Robotniczą (PPR). Był to powrót do koncepcji z 1945 roku $^{34}$.

Niezmiernie ważnym elementem funkcjonowania IV Zarządu WiN było utrzymywanie łączności z Delegaturą Zagraniczną Zrzeszenia WiN kryptonim

31 Z. Zblewski, Próba aktywowania..., s. 258; A. Dziuba, op. cit., s. 171.

32 Z. Woźniczka, op. cit., s. 98; K. Krajewski, Siatki wywiadowcze Obszaru Poludniowego działajace na terenie Obszaru Centralnego Zrzeszenia WiN, [w:] W sieci. Powojenne polskie siatki wywiadowcze (AK-NIE-DSZ-WiN, PSZ) w latach 1944-1955, red. M. Bechta, Warszawa 2016, s. $246-247$.

33 Z. Zblewski, Okręg Krakowski.., s. 542-543.

34 Ibidem, s. 244-245. 
„Dardanele”. Jej początki sięgały września 1946 roku (formalnie powstała w styczniu 1947 roku), kiedy to dwóch delegatów WiN - Stefan Rostworowski i Józef Maciołek - przedostało się z Polski do Wielkiej Brytanii. Delegatura uznawała władzę prezydenta RP na uchodźstwie oraz posiadała związki z emigracyjnymi strukturami wojskowymi, znajdowała się natomiast poza strukturami rządu polskiego na uchodźstwie ${ }^{35}$. Jej aktywna działalność wśród środowisk emigracyjnych oraz nawiązanie kontaktu $\mathrm{z}$ agendami rządów państw zachodnich (jak Belgia, Francja, Holandia, Wielka Brytania) i z prezesem Kongresu Polonii Amerykańskiej (choć to spotkanie nie przyniosło spodziewanych efektów) umożliwiły uświadamianie rozmówcom, że w Polsce nadal istnieje i działa silny ruch oporu antykomunistycznego w postaci Zrzeszenia WiN. To zaś pozwoliło na pozyskanie środków pieniężnych, a tym samym zakończyły się ciągłe problemy finansowe WiN. Zainteresowanie i pozytywne nastawienie do działalności antykomunistycznej Delegatury i WiN w kraju nastąpiło po przemówieniu Harry’ego Trumana, wygłoszonym 12 marca 1947 roku w Kongresie USA. Przeszło ono do historii jako początek tzw. doktryny Trumana, mającej zerwać z polityką „odprężenia” Franklina D. Roosevelta i rozpocząć działania mające na celu powstrzymanie ekspansji komunistów ${ }^{36}$.

Konsekwentna działalność Delegatury kierowanej przez ppłk. Józefa Maciołka „Romana” doprowadziła do podpisania we wrześniu 1947 roku umowy z brytyjską Secret Intelligence Service (SIS), w korespondencji wewnętrznej między Delegaturą Zagraniczną a IV ZG określaną kryptonim „Agnieszka”. Delegatura zobowiązała się w umowie z SIS do regularnego przekazywania Brytyjczykom sprawozdań wywiadowczych przychodzących z kraju. W zamian strona brytyjska zobowiązywała się do przekazywania wsparcia finansowego dla działalności $\mathrm{WiN}^{37}$.

Sprawozdania wywiadowcze sporządzano na podstawie informacji zbieranych przez siatki wywiadowcze WiN. W 1947 roku były to resztki struktury ukrytej pod kryptonimem „Iskra”, która wcześniej, do przełomu czerwca i lipca 1946 roku, funkcjonowała pod kryptonimem „Stomil”. Zaczęto ją tworzyć prawdopodobnie już we wrześniu 1945 roku w ramach Obszaru Południowego WiN. Jej organizatorem i szefem był wspomniany wcześniej Józef Maciołek.

35 S. Łukasiewicz, Partia w warunkach emigracji. Dylematy Polskiego Ruchu Wolnościowego „Niepodległość i Demokracja” 1945-1994, Lublin-Warszawa 2014, s. 602 i n.

36 „Dardanele”. Delegatura WiN-u za granica (1946-1949), wstęp, dobór tekstów, przypisy S.J. Rostworowski, Wrocław 2000, s. 48, 50, 54-56. Zob. więcej: Zrzeszenie „,Wolność i Niezawisłość" w dokumentach. Delegatura Zagraniczna WiN, red. J. Huchlowa, M. Huchla, t. 4, Wrocław 1998, s. 41 i n., 81-85, 255-258.

37 „Dardanele”. Delegatura WiN-u..., s. 57-58, 66, 71-72. 
Po krótkim okresie (wrzesień-listopad 1946), kiedy pracami „Iskry” zarządzał Stefan Sieńko „Wiktor”, kolejnym kierownikiem tej komórki został mjr Mieczysław Kawalec „Iza”, który od stycznia 1947 roku był kierownikiem Wydziału Informacji i Propagandy kryptonim „Instytut Bakteriologiczny” w IV ZG WiN ${ }^{38}$. Ostateczny kształt sprawozdań, powstających w oparciu o materiał zgromadzony przez wywiadowców „Iskry” oraz umieszczony w sprawozdaniach spływających z poszczególnych okręgów, nadawał Stefan Sieńko „Wiktor”, stojący na czele Biura Studiów (kryptonim „Oddział Zakaźny”) ${ }^{39}$.

W trakcie odbywających się konferencji ścisłego kierownictwa WiN (m.in. przełom lipca i sierpnia 1947 roku w Majewie koło Jeleniej Góry) dyskutowano nad referatami materiałowymi wygłaszanymi przez uczestników spotkania, a także omawiano „Wytyczne do programu ideowego organizacji WiN” oraz debatowano nad stosunkiem WiN do Polskiego Ruchu Wolnościowego (PRW) „Niepodległość i Demokracja” (NiD). Łukasz Ciepliński miał poinformować, że WiN był przedłużeniem „NiD” w Polsce, a „NiD” był przedłużeniem WiN-u za granicą. Był to efekt działań i uzgodnień poczynionych przez Delegaturę Zagraniczną WiN ${ }^{40}$. Warto zwrócić uwagę, że kierownictwo IV Zarządu prowadziło prace planistyczne nad tym, czym organizacja mogłaby się stać w przyszłości. Dyskutowano m.in. nad wizją przekształcenia jej w Polski Ruch Odrodzenia Narodowego $(\mathrm{PRON})^{41}$. Niestety, dyskusje planistyczne stały się niewykonalne na skutek nasilających się operacji UB.

W dniu 26 września 1947 roku w Przemyślu funkcjonariusze Wojewódzkiego Urzędu Bezpieczeństwa Publicznego (WUBP) w Rzeszowie aresztowali kpt. Władysława Kobę „Tora”, kierownika Okręgu Rzeszowskiego WiN ${ }^{42}$. Sześć dni później - 2 października - w Krakowie, w umówionym miejscu spotkania z kpt.

38 Więcej na ten temat zob. W. Frazik, Siatki wywiadowcze Obszaru Poludniowego Zrzeszenia „Wolność i Niezawistość”, [w:] W sieci..., s. 290-291, 294, 295.

39 Ibidem, s. 295. O działalności sitek wywiadowczych na terenie byłego Obszaru Centralnego WiN zob. więcej: K. Krajewski, Siatki wywiadowcze Obszaru Poludniowego działajace na terenie Obszaru Centralnego Zrzeszenia WiN, [w:] W sieci..., s. 246 i n.

40 Zob. więcej: Z. Zblewski, Okręg Krakowski.., s. 552-556; ,,Dardanele”. Delegatura WiN-u..., s. 45, 47, 48. Relacje między „NiD” i Delegacją Zagraniczną (a tym samym z WiN) skomplikowały się po wybraniu na stanowisko prezydenta RP Augusta Zaleskiego w czerwcu 1947 roku (zob. „Dardanele”. Delegatura WiN-u..., s. 71).

41 Z. Woźniczka, op. cit., s. 101. Por. Z. Zblewski, Okręg Krakowski.., s. 557; G. Ostasz, Okręg Rzeszowski Zrzeszenia „Wolność i Niezawistość”. Model konspiracji, struktura, dzieje, Rzeszów 2006, s. 243-244. Kierownictwa okręgów otrzymały „Kwestionariusz programowy”, nad którym miały przeprowadzić dyskusję i zdefiniować swoje stanowisko odnośnie do projektu.

42 Z.K. Wójcik, Władysław Antoni Koba..., s. 284. Proces rozpracowywania struktur rzeszowskiego WiN przez UB w szczegółowy sposób przedstawiono w pracy: Rozpracowanie i likwidacja 
„Torem” funkcjonariusze UB zatrzymali kpt. Franciszka Błażeja, kierownika Obszaru Południowego ${ }^{43}$. Z tego powodu na naradzie „prezydium” ZG WiN odbytej 10 października 1947 roku w Zakopanem zdecydowano o zawieszeniu kontaktów organizacyjnych i wszelkiej aktywności. Dalsze decyzje miano podjąć po wyjaśnieniu sytuacji ${ }^{44}$. Nie zahamowało to postępów UB w rozpracowywaniu struktur WiN i przeprowadzaniu dalszych aresztowań: Łukasza Cieplińskiego ujęto 27 listopada w Zabrzu; Józefa Batorego - 2 grudnia na punkcie kontaktowym w Warszawie; Adama Lazarowicza - 4 grudnia w Żninie, gdzie mieszkała jego rodzina; Ludwika Kubika - 9 grudnia; Karola Chmiela - 12 grudnia w Krakowie; Józefa Rzepkę - 25 stycznia 1948 roku w Katowicach; Mieczysława Kawalca - 29 stycznia lub 1 lutego w Poroninie.

Do czasu zatrzymania Mieczysław Kawalec jako pełniący obowiązki prezesa próbował bezskutecznie odbudować IV ZG WiN. Po jego ujęciu funkcjonariusze MBP rozpoczęli budowę fikcyjnego zarządu głównego WiN, który w historiografii nazwano „V Komendą WiN”, a całą operację ukryto pod kryptonimem „Cezary” (więcej o tej operacji w dalszej części tekstu).

\section{STRUKTURY OKRĘGOWE}

W okresie poamnestyjnym działały jedynie cztery związki konspiracyjne, które były określane mianem struktury okręgowej. Trzy z nich funkcjonowały na terenie dwóch województw: dwa na terenie województwa warszawskiego (Okręg NZW „Orzeł”, „Tęcza”; 11. Grupa Operacyjna NSZ) oraz jeden na terenie województwa białostockiego (Okręg NZW Białystok kryptonim „Chrobry”, „XV”). Ostatni związek konspiracyjny miał charakter eksterytorialny - był to Eksterytorialny Okręg Wileński Armii Krajowej (AK).

Spośród omawianych struktur okręgowych jedynie Eksterytorialny Okręg Wileński AK od 1945 roku posiadał formalne zwierzchnictwo Naczelnego Wodza, pozostałe zaś prowadziły działalność samodzielną. Organizowanie na nowo Okręgu Wileńskiego AK w pojałtańskiej Polsce rozpoczęto w sierpniu 1945 roku, po zakończeniu ewakuacji jego żołnierzy z terenów Wileńszczyzny. Funkcję komendanta pełnił mjr/ppłk Antoni Olechnowicz „Pohorecki”. Główne zadanie Okręgu polegało na udzielaniu pomocy najbardziej potrzebującym jego członkom oraz zbieraniu informacji wywiadowczych. Okręgowi podporządkowane były

Rzeszowskiego Wydziału WiN w dokumentach UB (1945-1949), wybór, wstęp i oprac. T. Balbus, Z. Nawrocki, Warszawa 2001.

43 Z. Zblewski, Okręg Krakowski.., s. 567.

44 Z. Woźniczka, op. cit., s. 103; Z.K. Wójcik, Adam Lazarowicz..., s. 291. 
5. i 6. Wileńska Brygada AK ${ }^{45}$. Na początku marca 1947 roku ppłk „Pohorecki” powrócił do Polski z Paryża, gdzie miał odbyć osobiste spotkanie z przedstawicielem Naczelnego Wodza. Dowodzony przez niego Okręg nadal miał być bezpośrednio podporządkowany Naczelnemu Wodzowi. Z treści jego wypowiedzi wynikało, że konflikt między Zachodem a Związkiem Sowieckim jest bliski i nieunikniony. Zgodnie z wytycznymi do tego czasu Okręg miał pozostawać w ścisłej konspiracji, bez prowadzenia działań zbrojnych i propagandowych. Próby organizowania partyzantki miały być ograniczane. Komenda Okręgu miała pomagać jego członkom na różne sposoby (m.in. w ramach legalizacji). Komendant z własnej inicjatywy polecił jednak organizowanie patroli dywersyjnych, a także gromadzenie informacji, głównie tych dotyczących sytuacji ludności z Wileńszczyzny $^{46}$. Po zakończeniu akcji ujawnieniowej wiosną 1947 r. na Podlasiu nadal operowała kadrowa (licząca około 30 partyzantów) 6. Wileńska Brygada AK dowodzona przez kpt. Władysława Łukasiuka „Młota”. Zgodnie z wytycznymi ppłk. „Pohoreckiego” miała ona prowadzić działania jedynie w samoobronie ${ }^{47}$.

Największym potencjałem organizacyjnym mógł się pochwalić Okręg NZW Białystok kryptonim „Chrobry”, „XV”, mimo że na skutek ujawnienia rezerwuar jego sił uległ uszczupleniu mniej więcej o połowę. $Z$ szacunkowych danych wynika, że po zakończeniu amnestii w siatce terenowej Okręgu pozostało około 2 tys. członków ${ }^{48}$. Wspomniane okręgi NZW wypracowały różniące się od siebie modele organizacyjne. Okręg białostocki zachował strukturę wojskową, przy czym po ujawnieniu przestał funkcjonować sztab komendy Okręgu, a jednoosobowe dowództwo sprawował jego komendant. Natomiast członkowie NZW zgrupowani byli w komendach powiatowych: Łomża „Podhale”, Wysokie Mazowieckie „Mazur”, Bielsk Podlaski „Burza” oraz Ostrów Mazowiecka „Noc" -"Tatry” (początkowo tereny tego powiatu były objęte organizacyjnie przez komendę łomżyńską, do wydzielenia odrębnej jednostki doszło dopiero w 1948 roku). W komendach powiatowych nadal funkcjonowały kilkuosobowe sztaby (szef Wydziału I, szef Wydziału II, szef Pogotowia Akcji Specjalnej [PAS], podoficer gospodarczy). Ponadto nadal istniał podział na bataliony i kompanie itd. Wraz z upływającym czasem i przerzedzającymi się szeregami organizacji

\footnotetext{
45 P. Niwiński, Okręg Wileński AK w latach 1944-1948, Warszawa 1999, s. 111-121; Atlas...,

46 P. Niwiński, Okręg Wileński.., s. 232-233, 236.

47 Ibidem, s. 239-240. Szerzej na temat działalności 6. Wileńskiej Brygady AK zob. K. Krajewski, T. Łabuszewski, , Łupaszka”, „,Młot”, ,Huzar”. Działalność 5. i 6. Brygady Wileńskiej AK (1944-1952), Warszawa 2002, s. 641 i n.

48 P. Łapiński, Władysław Żwański (1896-1948), [w:] Słownik biograficzny, t. 3: Konspiracja i opór społeczny w Polsce 1944-1956, red. T. Balbus, Kraków-Warszawa-Wrocław 2007, s. 630.
} s. 342. 
sztaby komend powiatowych i struktura terenowa zanikały, a obsada ograniczała się jedynie do komendanta powiatu i szefa PAS. Dochodziło też do łączenia poszczególnych komend pod jednym dowództwem (połączono komendy łomżyńską i wysokomazowiecką) ${ }^{49}$. Na początku 1948 roku liczebność okręgu miała wynosić 300-600 członków ${ }^{50}$.

W okresie poamnestyjnym białostockim Okręgiem NZW dowodziło dwóch komendantów. Pierwszym z nich był ppłk Władysław Żwański „Błękit”. W czasie okupacji niemieckiej był on m.in. komendantem powiatu NSZ Ostrów Mazowiecka. Po krótkim epizodzie służby w ludowym Wojsku Polskim, w kwietniu 1945 roku zdezerterował i zasilił szeregi organizowanego Okręgu NZW Białystok („XV”, „Chrobry”), gdzie sprawował funkcję szefa sztabu, a od kwietnia 1946 roku był jego komendantem. Cieszył się niekwestionowanym autorytetem wśród członków podziemia narodowego i miejscowej ludności. Przez pierwszy rok pełnienia funkcji zreorganizował i usprawnił działalność podległych sobie struktur. Dużą wagę przykładał do działalności propagandowej.

Nieco inaczej wyglądała kwestia zorganizowania Okręgu NZW „Orzeł”. Przed amnestią funkcjonował on pod kryptonimami „Mazowsze”, „XVI” (obejmował teren powiatu Ostrołęka, północno-zachodnią część powiatu Łomża i pogranicze byłych Prus Wschodnich). W czasie amnestii jego komendant, kpt. Zbigniew Kulesza „Młot”, opuścił teren i - nie informując o tym nikogo - ujawnił się 22 kwietnia 1947 roku w Wałbrzychu ${ }^{51}$. Co gorsza, z kadry dowódczej Okręgu nie pozostał żaden oficer. Kiedy informacja o ujawnieniu kpt. „Młota” dotarła do szefa PAS Okręgu por. Józefa Kozłowskiego „Lasa”, ten zwołał odprawę podoficerów, w trakcie której poinformował o aktualnej sytuacji. Wszyscy zebrani byli zdeterminowani, aby kontynuować dalszą walkę. Będąc rozczarowanymi postawą oficerów, nowego komendanta postanowili wybrać spośród siebie, w sposób demokratyczny. Jednogłośnie wybrano por. „Lasa” („Wisa”) ${ }^{52}$. Nowy komendant na terenie powiatu ostrołęckiego pojawił się w czerwcu 1944

49 J. Kułak, Powstanie i działalność Narodowego Zjednoczenia Wojskowego na terenie powiatu Łomża (Komenda Okręgu NZW Biatystok) 1944-1948, [w:] Europa nieprowincjonalna. Przemiany na ziemiach wschodnich dawnej Rzeczypospolitej (Biatoruś, Litwa, Lotwa, Ukraina, wschodnie pogranicze III Rzeczypospolitej Polskiej w latach 1772-1999, red. K. Jasiewicz, Warszawa 1999, s. 840-841; S. Poleszak, Podziemie antykomunistyczne..., s. 357-358.

50 M. Bechta, W.J. Muszyński. op. cit., s. 282.

51 K. Kacprzak, Podziemie zbrojne na Mazowszu Pólnocnym w walce w systemem komunistycznym 1945-1952, Warszawa 2011, s. 211 i n.; M. Bechta, W.J. Muszyński, op. cit., s. 233, 235.

52 K. Kacprzak, op. cit., s. 240-241; Kryptonim „Orzet”. Warszawski Okręg Zjednoczenia Wojskowego w dokumentach 1947-1954, red. K. Krajewski, T. Łabuszewski, J. Pawłowicz, L. Żebrowski, Warszawa 2004, s. 146-149; S. Poleszak, Podziemie antykomunistyczne..., s. 371-372. 
roku. Przybył tam wraz z wycofującymi się niemieckimi jednostkami wojskowymi w szeregach tzw. Legionu Polskiego (białoruska formacja policyjna). Po zabiciu oficera niemieckiego Kozłowski wraz z grupą legionistów dołączył do miejscowej AK. Do jesieni 1945 roku działał w ostrołęckim podziemiu akowskim i poakowskim, po czym związał się z konspiracją narodową ${ }^{53}$.

Pracami Okręgu kierował kilkuosobowy sztab. Warto zwrócić uwagę na ciekawe rozwiązanie organizacyjne, które zastosowano, powołując to ogniwo do życia. Terytorialnie wydzielono osiem komend powiatowych, zrezygnowano jednak z utrzymywania wojskowej struktury terenowej (z podziału na bataliony, kompanie, plutony itp.). Całość pracy konspiracyjnej skupiała się w kilkunastoosobowych grupach zbrojnych, które równocześnie stanowiły sztaby komend powiatowych i oddziały PAS (często operujące w kilkuosobowych patrolach). Liczyły one w sumie około 115-120 ludzi na terenie całego Okręgu. Nastąpiło skumulowanie funkcji szefa PAS powiatu, komendanta powiatu i jednocześnie dowódcy patrolu bojowego. Terytorialnie Okręg obejmował powiaty: Ciechanów, Ostrołęka, Przasnysz, częściowo Łomża, Maków Mazowiecki i Szczytno ${ }^{54}$.

Jako ostatnią strukturę okręgową należy wymienić 11. Grupę Operacyjną NSZ. W niektórych opracowaniach jest ona błędnie określana mianem Okręg XIII lub XXIII NZW ${ }^{55}$. Była to organizacja używająca nazwy NSZ, ale działająca w ramach NZW (Obszar I). Do jej utworzenia doszło latem 1946 roku. Terenem jej aktywności było pogranicze województwa warszawskiego i bydgoskiego (powiaty: Sierpc, Mława, Lipno, Rypin, Włocławek, Płock, Płońsk oraz częściowo Działdowo i Ciechanów) ${ }^{56}$. Jej oparcie stanowili byli członkowie II Okręgu NSZ, którzy w lipcu 1944 roku w ramach macierzystej organizacji scalili się z AK i znaleźli się w szeregach Inspektoratu Płocko-Sierpeckiego AK. Po rozwiązaniu AK w styczniu 1945 roku kontynuowali działalność podziemną przeciwko

53 K. Krajewski, T. Łabuszewski, Józef Kozłowski (1909-1949), [w:] Słownik biograficzny, t. 3, s. $268-269$.

${ }^{54}$ K. Kacprzak, op. cit., s. 243-244; S. Poleszak, Podziemie antykomunistyczne..., s. 372. Zob. także: W. Brenda, Okręg „,Orzet” NZW na pótnocnym Mazowszu i jego kontynuatorzy, [w:] Ostatni leśni, red. T. Łabuszewski, Warszawa 2003, s. 32 i n.

55 K. Komorowski, Polityka i walka. Konspiracja zbrojna obozu narodowego 1939-1945, Warszawa 2001, s. 510; R. Juszkiewicz, Walka Niezłomnych-Wyklętych na Ziemi Mławskiej w latach 1945-1953, Mława 2016, s. 161; Informator o nielegalnych antypaństwowych organizacjach i bandach zbrojnych działajacych w Polsce Ludowej w latach 1944-1956, Warszawa 1964 (reprint: Lublin 1993), s. 119. Źródło tej pomyłki wyjaśnił Jacek Pawłowicz, ale w tytule swojego artykułu nadal używał określenia: XXIII Okręg NZW. Zob. J. Pawłowicz, Ostatni , leśni” zachodniego Mazowsza: XXIII Okręg Narodowego Zjednoczenia Wojskowego - 11 Grupa Operacyjna Narodowych Sit Zbrojnych, [w:] Ostatni leśni..., s. 67-70.

56 J. Pawłowicz, Ostatni „leśni” zachodniego Mazowsza..., s. 67-70. 
strukturom władzy komunistycznej. Walczyli w miejscowych grupach samoobrony. Współorganizatorem i komendantem 11. Grupy Operacyjnej NSZ był por. Stefan Bronarski „Liść”, „Roman” (członek NSZ, po scaleniu z AK latem 1944 roku dowódca Kedyw Inspektoratu Płocko-Sierpeckiego i Obwodu Płock) $)^{57}$.

Potencjał organizacji - tak jak w przypadku dwóch wcześniej opisanych okręgów - został poważnie nadwątlony przez akcję ujawnieniową z wiosny 1947 roku. Doszło do częściowej demobilizacji w jej szeregach, m.in. rozwiązano patrole bojowe (Patrole do Walki z Bezprawiem). Starano się zalegalizować wychodzących z podziemia ludzi. Dowódca traktował ujawnienie ,jako manewr taktyczny celem przechowania żywotnych sił Narodu"58. Represyjna polityka władz wobec ujawnionych członków podziemia oraz mieszkańców z nimi sympatyzujących spowodowała jednak odmrożenie działalności konspiracyjnej i powroty w jej szeregi byłych członków. Warto wspomnieć, że w okresie od połowy 1945 roku do kwietnia 1947 roku na terenie objętym działalnością 11. Grupy Operacyjnej NSZ dużą aktywność przejawiał lokalny związek ROAK, czyli Obwód „Mewa”, który obejmował powiat Sierpc oraz częściowo Płońsk, Płock, Mława (województwo warszawskie) i Rypin (województwo bydgoskie). Większość jego członków ujawniła się wiosną 1947 roku. Amnestię zbojkotował około trzydziestoosobowy, bardzo aktywny oddział por. Franciszka Majewskiego „Słonego”, który był podkomendnym por. Bronarskiego „Romana” w ramach Kedyw Inspektoratu Płocko-Sierpeckiego AK ${ }^{59}$. W listopadzie 1947 roku doszło do formalnego włączenia oddziału por. „Słonego" i jego zaplecza w struktury 11. Grupy Operacyjnej NSZ. W trakcie odprawy, na której do tego doszło, por. Bronarski wzywał do wytrwałości w walce i sugerował możliwy wybuch wojny między USA a ZSRR, w wyniku której Polska odzyska niepodległość. Dowództwo organizacji przebywało w Warszawie, skąd kierowało podległym ogniwem. W drugiej połowie 1947 roku miało ono liczyć około kilkuset członków. Dla potrzeb wewnątrzorganizacyjnych wydzielono trzy rejony operowania: I - powiaty Płock i Płońsk; II - powiat Sierpc i północna część powiatu Mława; III - powiat Rypin i południowa część powiatu Mława ${ }^{60}$. Wszystkie trzy okręgi przejawiały bardzo podobną aktywność organizacją. Główny nacisk kładziono na działalność zbrojną i propagandową.

\footnotetext{
57 Ibidem, s. 70; idem, Stefan Bronarski (1916-1951), [w:] Stownik biograficzny, t. 2, s. 44.

58 Idem, Ostatni „leśni” zachodniego Mazowsza..., s. 71; M. Bechta, W.J. Muszyński, op. cit., s. 246.

59 J. Pawłowicz, Stefan Bronarski.., s. 331-332.

60 Idem, Ostatni „leśni” zachodniego Mazowsza..., s. 71-72; Atlas..., s. 232; M. Bechta, W.J. Muszyński, op. cit., s. 247.
} 
W okręgu „Orzeł” wydawano pismo podziemne „Głos z Podziemia”. Pierwszy jego numer ukazał się w sierpniu 1947 roku. Rozkolportowano go w 400 egzemplarzach. Z kolei trzeci numer pisma, który ukończono w kwietniu 1948 roku, miał nakład tysiąca egzemplarzy. Kolejny numer miał mieć nakład 1100 egzemplarzy, ale w całości wpadł $\mathrm{w}$ ręce UB podczas likwidacji bazy komendy 25 czerwca 1948 roku. Ponadto powielano ulotki, których nakład często sięgał kilku tysięcy egzemplarzy. Był to znaczący wysiłek propagandowy ${ }^{61}$. W okręgu białostockim kolportowano wydawnictwa konspiracyjne: „Głos znad Narwi”, „Polak”, „Walka” oraz „Głos z Podziemia”. Ten ostatni tytuł był wydawany do kwietnia 1948 roku $^{62}$. Podobnie było w przypadku 11. Grupy Operacyjnej NSZ, która - tak jak w okresie przedamnestyjnym - wydawała „Mazowiecki Biuletyn Informacyjny”, który ukazywał się jeszcze w 1948 roku ${ }^{63}$.

W miesiącach letnich 1948 roku wszystkie cztery z omawianych struktur okręgowych stały się celem silnych i celnych uderzeń ze strony UB, w wyniku których dowództwa Eksterytorialnego Okręgu Wileńskiego AK oraz 11. Grupy Operacyjnej NSZ zostały całkowicie rozbite. Działalność kontynuowały okręgi NZW: „Orzeł” (jako „Tęcza”) i białostocki „Chrobry”. W pierwszym przypadku o schedę po por. „Wisie” rywalizowało dwóch komendantów powiatowych: chor. Witold Borucki „Babinicz” i st. sierż. Mieczysław Dziemieszkiewicz „Rój”. Obaj reprezentowali młode pokolenie konspiratorów: pierwszy urodził się w 1924 roku, a drugi - w 1925 roku. Skuteczniejsze działania podjął chor. Borucki, który na zwołanej 10 lipca 1948 roku odprawie został wybrany przez zebranych na nowego komendanta okręgu, który od tego czasu posługiwał się nowym kryptonimem „Tęcza”. Z ustaleń Krzysztofa Kasprzaka wynika, że po reorganizacji w skład okręgu wchodziło jeszcze pięć komend powiatowych. Poza jurysdykcją chor. „Babinicza” znalazły się dwie komendy: pierwsza dowodzona przez wspomnianego st. sierż. „Roja”, a druga - przez chor. Hieronima Rogińskiego „Roga”. Wynikało to zapewne z przyczyn ambicjonalnych ${ }^{64}$. Okręg nie przejawiał tak szerokiej aktywności jak poprzednio, a wynikało to z coraz cięższych warunków

61 K. Kacprzak, op. cit., s. 248-251.

62 P. Łapiński, Władysław Żwański..., s. 627-629.

63 J. Pawłowicz, Ostatni „leśni” zachodniego Mazowsza..., s. 71-72; Atlas..., s. 232; M. Bechta, W.J. Muszyński, op. cit., s. 247.

${ }^{64}$ K. Kacprzak, op. cit., s. 280-282. Por. K. Krajewski, Podziemie niepodległościowe w powiecie Ostrołęka po 1944 r., [w:] Powiat Ostrołęka. Materiaty z sesji naukowej „Powiat Ostrołęka w pierwszej dekadzie rządów komunistycznych" zorganizowanej 23 października 2008 r. przez Oddziat Instytutu Pamięci Narodowej w Warszawie i prezydenta Ostrołęki, t. 3: Mazowsze i Podlasie w Ogniu 1944-1956, red. K. Krajewski, Warszawa 2009, s. 133-136; M. Bechta, W.J. Muszyński, op. cit., s. 239-241. 
pracy podziemnej i mniejszych możliwości technicznych. Warto zauważyć, że w drugiej połowie 1948 roku poszczególne komendy powiatowe jednak były w stanie wyprodukować i rozkolportować na terenie swojego działania po 500 egzemplarzy ulotek ${ }^{65}$. Stojący na czele Komendy Okręgu „Tęcza” chor. „Babinicz” przetrwał do 19 sierpnia 1949 roku, kiedy został zabity przez utworzoną przez UB grupę morderców z tzw. V Kolumny, złożoną z partyzantów NZW ${ }^{66}$.

Śmierć płk. „Błękita” stanowiła formalny kres Okręgu NZW Białystok, mimo że jako ostatni jego komendant wskazywany jest ppor. cz.w. Kazimierz Żebrowski „Bąk”. On sam nigdy nie używał takiej tytulatury, a rozkazy podpisywał jako komendant połączonej komendy łomżyńsko-wysokomazowiecko-ostrowskiej („,Podhale”/’Mazur"/"Tatry”) ${ }^{67}$. Z kresem dowodzenia tym ogniwem przez ppor. „Bąka” wiąże się jeden z bardziej dramatycznych opisów: „»Bąk« z synem biegną w kierunku olszyny. Ci z podwórka grzeją do nich. »Konar« zachwiał się i krzyczy: »Tato jestem ranny! « i zwalił się na ziemię. »Bąk« zaraz się wrócił, ukląkł przy głowie syna, przeżegnał się, przystawił mu pistolet do głowy i dwa razy strzelił. Tamci krzyczą, żeby przestał się bić. »Bąk« strzelił sobie w głowę. Bój się skończył [...]"68. Zginęli 3 grudnia 1949 roku we wsi Mężenin w powiecie Łomża.

\section{ORGANIZACJE LOKALNE}

Zarówno w okresie przedamnestyjnym, jak i po kwietniu 1947 roku na terenie całego kraju istniały samodzielne organizacje lokalne. Część z nich kontynuowała działalność zapoczątkowaną w okresie 1945-1947 pomimo możliwości skorzystania $\mathrm{z}$ amnestii, inne zaś powstawały w okresie poamnestyjnym jako skutek polityki represyjnej prowadzonej przez instytucje władzy komunistycznej. Tylko niektóre z nich posiadały strukturę wojskową, a w jej ramach działały

65 K. Kacprzak, op. cit., s. 285. W sierpniu 1948 roku na terenie powiatów Ciechanów, Maków Mazowiecki, Ostrołęka i Przasnysz rozkolportowano ulotki „Głos Wolności”, w których informowano o rozbiciu komendy okręgu i innych sprawach związanych z działalnością organizacji. W tym samym miesiącu na terenie powiatów Pułtusk i Maków Mazowiecki rozpowszechniono 500 egzemplarzy ulotki „Do zdrajców narodu polskiego”.

${ }^{66}$ K. Krajewski, T. Łabuszewski, Zamordowani mordercy. Sprawa „V Kolumny”- czyli zabójstwa na zlecenie, „Zeszyty Historyczne WiN-u” 2009, nr 30, s. 193; K. Kacprzak, op. cit., s. 290291; K. Krajewski, T. Łabuszewski, Witold Borucki „Dąb”, „Babinicz”, [w:] Zapomniani wyklęci. Sylwetki żotnierzy powojennej konspiracji antykomunistycznej, Warszawa 2019, s. 64-65.

67 P. Łapiński, Rozbicie Komendy Powiatu NZW Łomża (wiosna 1947-wiosna 1948). Z dziejów wywiadu NZW na Białostocczyźnie, [w:] Wywiadowcza i kontrwywiadowcza działalność podziemia narodowego w latach 1944-1956, red. L. Żebrowski, Warszawa 2019, s. 102-103.

68 Reduty bez wojny, „Karta” 1996, nr 18, s. 34. 
oddziały partyzanckie. W większości przypadków liczebność tych grup wahała się od kilku do kilkudziesięciu członków, tylko w pojedynczych przypadkach liczyły one ponad 100 i więcej członków. Poniżej opisane przykłady to organizacje typu wojskowego. Natomiast inne organizacje prowadziły działalność ulotkową, propagandową czy sabotażową, a ich członkowie zbierali broń i prowadzili szkolenia wojskowe.

Tworzeniu tego rodzaju grup towarzyszyła pewnego rodzaju prawidłowość. Otóż powstawały one tam, gdzie istniały słabe struktury konspiracyjne lub nie było ich wcale. Były to przede wszystkim obszary województwa wrocławskiego, pomorskiego, poznańskiego olsztyńskiego, warszawskiego (z wyłączeniem jego północnej i wschodniej części ${ }^{69}$. W okresie przedamnestyjnym grupy lokalne nie działały na terenie województwa lubelskiego, ale w okresie po kwietniu 1947 roku działało ich już dwie.

Do początku drugiej połowy 1946 roku samodzielną i zapewne najsilniejszą organizacją lokalną było KWP. Z wyliczeń Tomasza Toborka wynika, że w szczytowym okresie liczyła ona ponad 2,5 tys. zaangażowanych w działalność członków, z czego około $1500 \mathrm{w}$ województwie łódzkim (KWP działało też na obszarach województwa śląskiego, poznańskiego, pomorskiego i kieleckiego). Jednak po ujęciu głównego pomysłodawcy utworzenia organizacji i jej dowódcy kpt. Stanisława Sojczyńskiego „Warszyca” (27 czerwca 1946 roku w Częstochowie) organizacja słabła. Przez kilka miesięcy jej potencjał próbował odbudować por. Jerzy Jasiński „Janusz”, ale mimo to organizacja była zdecydowanie słabsza, a jej liczebność nie przekraczała 400 członków. Wysiłki por. Janusza" przerwało jego aresztowanie wraz z II Komendą KWP w noc sylwestrową 1946 roku, a reszty dopełniła amnestia ${ }^{70}$. Na czele tzw. III Komendy KWP stanął sierż. Jan Małolepszy „Murat”. W tym czasie szeregi tej organizacji liczyły jedynie 60 partyzantów i około 200 współpracowników. Byli oni skupieni w sześciu oddziałach partyzanckich, głównie na terenie powiatu sieradzkiego i wieluńskiego $^{71}$. Po aresztowaniu 9 listopada 1948 roku sierż. „Murata” samodzielną działalność kontynuowały grupy zbrojne ${ }^{72}$.

Samodzielny Obwód Tomaszów Lubelski WiN, działający na południowo-wschodniej Lubelszczyźnie, był przykładem związku, który powstał z byłych

69 Atlas..., s. 204, 233-236, 344-346, 470-471, 510-511.

70 T. Toborek, op. cit., s. 73-74; K. Jasiak, Działalność partyzancka Konspiracyjnego Wojska Polskiego. Z dziejów II konspiracji w środkowej Polsce w latach 1945-1955, Wieluń-Opole 2008, s. $325-331$.

71 T. Toborek, op. cit., s. 189-207; K. Jasiak, Działalność partyzancka..., s. 361 i n.; idem, Jan Małolepszy (1906-1949), [w:] Stownik biograficzny, t. 3, s. 340-341.

72 K. Jasiak, Działalność partyzancka..., s. 429-442. 
członków siatki Obwodu Tomaszów Lubelski AK i WiN, chcących kontynuować działalność konspiracyjną. Działał on od wiosny 1947 roku, a jego komendant - por. Stefan Kobos „Wrzos” - został aresztowany dopiero w styczniu 1956 roku. Liczebność organizacji szacowana była na około 100 osób $^{73}$. Do początku 1951 roku bardzo aktywną działalność prowadził podporządkowany mu oddział partyzancki dowodzony przez chor. Jana Leonowicza „Burtę”. Kolejną strukturą lokalną był II Inspektorat Zamojski AK. Jego początki sięgały września 1947 roku, kiedy w klasztorze oo. Bernardynów w Radecznicy doszło do spotkania konspiratorów. Złożenie przysięgi przez jego dowództwo miało miejsce w marcu 1948 roku. Reaktywacja działalności konspiracyjnej była skutkiem represji, które dotykały ujawnionych członków WiN. Model konspirowania odwoływał się do tradycji sprzed amnestii. Na czele inspektoratu stał inspektor mjr Marian Pilarski „Jar”, „Olgierd” i jego sztab. Struktura terenowa składała się z czterech obwodów odpowiadającym terytorialnie powiatom (Biłgoraj, Hrubieszów, Tomaszów Lubelski, Zamość). Inspektoratowi podporządkowało się kilka oddziałów partyzanckich, tzw. Oddziałów Lotnej Żandarmerii, które w sumie liczyły 30-40 partyzantów. Szacunkowa liczebność tego związku konspiracyjnego to 200-400 osób. Jego masowość, zważywszy na okres, w którym działał, stała się przyczyną rozpracowania go przez UB i rozbicia wiosną $1950 \mathrm{roku}^{74}$.

Wydaje się, że symboliczny kres podziemia strukturalnego w Polsce nastąpił pod koniec 1949 roku wraz ze śmiercią ppor. Kazimierza Żebrowskiego „Bąka”, uznawanego za ostatniego komendanta Okręgu NZW Białystok.

\section{ODDZIAŁY I GRUPY ZBROJNE}

Niezmiernie istotnym elementem mapy oporu po kwietniu 1947 roku były oddziały partyzanckie. Część z nich działała samodzielnie, a część uznawała zwierzchnictwo większej organizacji. Wraz z upływającym czasem i likwidacją przez UB kolejnych siatek okręgowych czy lokalnych coraz więcej oddziałów działało samodzielne. Według szacunkowych danych zawartych w Atlasie polskiego podziemia niepodległościowego 1944-1956 w okresie od kwietnia 1947

73 W. Hanus, Jeden z ostatnich. Stefan Kobos ,,Wrzos” (1900-1976). Przyczynek do dziejów konspiracji na Narolszczyźnie, Rzeszów 2019, s. 124-137; J. Wołoszyn, Stefan Kobos „,Michorowski”, ,Wrzos”, [w:] Ostatni komendanci. Ostatni żotnierze 1951-1963, red. M. Biernat, Warszawa [2016], s. 79, 84, 86-87.

74 R. Wnuk, Konspiracja akowska o poakowska na Zamojszczyźnie od lipca 1944 do 1956, Zamość 1993, s. 152-160; B. Szyprowski, II Inspektorat Zamojski Armii Krajowej 1948-1950, cz. I, „Wyklęci” 2016, nr 3, s. 146-152; idem, II Inspektorat Zamojski Armii Krajowej 1948-1950, cz. II, „Wyklęci” 2016, nr 4, s. 163-171. 
roku do końca grudnia 1950 roku działało co najmniej 130 oddziałów partyzanckich. Przez ich szeregi przewinęło się od ponad 1200 do niemal 1900 partyzantów (17-20\%) stanu oddziałów partyzanckich z okresu poprzedniego (styczeń 1946 - kwiecień 1947). Największe przerzedzenie „leśnych” szeregów nastąpiło w województwie katowickim, gdzie walkę kontynuowało jedynie $6 \%$ partyzantów sprzed amnestii, a także w województwach: poznańskim (8\%), krakowskim i łódzkim (10\%) oraz rzeszowskim (11\%). Najwyższy potencjał szeregi partyzanckie zachowały w województwach: warszawskim (44-48\%), białostockim (30-33\%) i lubelskim (20-22\%). Średnio przez oddział przewinęło się od 9 do 14 partyzantów.

W interesującym nas okresie największa liczba partyzantów przewinęła się przez oddziały o proweniencji narodowej. Przez 46 z nich przeszło od około 500 do 650 osób, czyli 34-38\% wszystkich wówczas walczących. Na sytuację tę wpływało istnienie sprawnie działających siatek NZW (okręgi: „Orzeł”, „Chrobry” i 11. Grupa Operacyjna NSZ). Były one swoistym magnesem dla oddziałów i ludzi, których dotychczasowe macierzyste związki konspiracyjne skorzystały z ujawnienia (ROAK, WiN). Dla przykładu oddział ROAK por. Franciszka Majewskiego „Słonego” po amnestii działał samodzielnie, a w listopadzie 1947 roku wszedł w skład 11. Grupy Operacyjnej NSZ. Z kolei partyzanci kpt. Kazimierza Kamieńskiego „Huzara” po samolikwidacji białostockiego WiN związali się z 6. Brygadą Wileńską AK. Latem 1949 roku „Huzar” został jej ostatnim dowódcą. Drugie pod względem liczebności były oddziały o nieustalonej proweniencji lub oddziały nieafiliowane. Przez 28 z nich przewinęło się od 240 do blisko 400 osób (20-21\%) ogółu walczących. Niemal tyle samo partyzantów przewinęło się przez oddziały powinowskie. Przez 26 oddziałów przeszło od 190 do 380.

Największa liczba partyzantów skupiona była na terenie województwa warszawskiego (we wschodniej i północnej jego części). W oddziałach operujących na tym terenie walczyło od 350 do około 500 ludzi (27-29\% wszystkich partyzantów w Polsce). Kolejne miejsce zajęło województwo lubelskie, gdzie przez partyzanckie szeregi przewinęło się od 200 do 245 (13\%) osób, a także województwo białostockie - od 150 do 300 partyzantów (12-16\%).

Po styczniu 1951 roku w Polsce działało jeszcze co najmniej 49 oddziałów partyzanckich, przez które przewinęło się od 260 do ponad 420 partyzantów. W tym okresie wciąż działało 11 oddziałów o proweniencji narodowej. Przeszło przez nie od 70 do 120 osób (26-29\% ogółu). Ponadto funkcjonowało 16 grup powinowskich, które liczyły od 60 do 120 partyzantów (23-28\%), a także około 10 oddziałów nieafiliowanych lub o nieustalonej proweniencji, łącznie od ponad 60 do 80 partyzantów (19-25\%), najwięcej w województwach: lubelskim 
- 100-140 (33-40\%), warszawskim - 50-90 (21\%) i białostockim - 30-80 (12-19\%). Na terenie tych trzech województw przez szeregi partyzanckie przewinęło się 70-75\% ogółu walczących. W województwie warszawskim walkę prowadziły jedynie oddziały wywodzące się z nurtu narodowego i 6 . Brygady Wileńskiej. W województwie białostockim natomiast oddziały powinowskie i narodowe dysponowały niemal takim samym potencjałem. Z kolei w województwie lubelskim najsilniejsze były grupy powinowskie oraz podporządkowane lokalnej organizacji - II Inspektoratowi Zamojskiemu $\mathrm{AK}^{75}$.

Analiza danych zawartych w Atlasie polskiego podziemia niepodległościowego 1944-1956 pozwala na prześledzenie losów co najmniej 134 oddziałów zbrojnych, które działały w okresie od końca amnestii 1947 roku do 1953 roku. Aż 41 z tych 134 oddziałów rozpoczęło swoją działalność przed kwietniem 1947 roku. Historia trzech z nich sięgała okresu okupacji niemieckiej. Były to oddziały dowodzone przez kpt. Zdzisława Brońskiego „Uskoka” (środkowa Lubelszczyzna), chor. Adama Kusza „Adama”, Garbatego” (przez dwa lata, do grudnia 1946 roku, dowodził nim ppor. Józef Zadzierski „Wołyniak”; pogranicze rzeszowsko-lubelskie) i Józefa Cieśli „Topora” (środkowa Rzeszowszczyzna; oddział działał w okresie 1944-1945, a później od 1949 roku). Kolejne dwa oddziały powstały w 1944 roku, zaraz po wkroczeniu Armii Czerwonej; 21 oddziałów zawiązało się w 1945 roku, a 14 - w 1946 roku. Ostatni z oddziałów powstałych przed amnestią 1947 roku rozpocząl aktywność w styczniu 1947 roku. Zdecydowana większość z nich powstała po zakończeniu amnestii - najwięcej w 1947 roku (43) i w 1948 roku (18). O ile rok 1947 to czas pewnego przeorganizowywania się struktur i oddziałów podziemia, o tyle wydaje się, że powstawanie grup zbrojnych w 1948 roku, co najmniej pewnej ich części, było spowodowane represjami wobec osób ujawnionych, nieujawnionych i podejrzewanych o związki z działalnością nielegalną, które na skutek tych działań decydowały się na ,powrót do lasu”. Na przestrzeni kolejnych lat powstawanie nowych grup było wyłącznie wynikiem działań represyjnych organów władzy komunistycznej. W 1949 roku takich grup zbrojnych powstało 15, w następnym roku - 11, w 1951 roku - 5, a w 1952 roku - jeszcze kolejne $2^{76}$.

Jeśli chodzi o działalność oddziałów zbrojnych w analizowanym okresie, to miała ona charakter zdecydowanie defensywny, a jej stopień pogłębiał się wraz

75 S. Poleszak, R. Wnuk, Oddziały zbrojne polskiego podziemia niepodległościowego i organizacje młodzieżowe - próba ujęcia statystycznego, [w:] Atlas..., s. LXV-LXVI, LXIX-LXXV.

76 Wykorzystano dane dotyczące oddziałów działających po 1947 roku na terenie całego obszaru Polski, które zawarte są w poszczególnych rozdziałach „wojewódzkich” Atlas polskiego podziemia niepodległościowego 1944-1956. 
z upływającym czasem. O ile w okresie 1945-1947 można mówić o pewnej specjalności oddziałów podziemia niepodległościowego, czyli rozbijaniu więzień i aresztów, o tyle po kwietniu 1947 roku nie odnotowuje się żadnej tego typu akcji. Pewnym wskaźnikiem aktywności podziemia była też skala rozbić/ rozbrojeń posterunków MO. Podczas gdy w okresie od sierpnia 1944 do kwietnia 1947 roku oddziały podziemia dokonały ponad 1300 tego typu akcji ${ }^{77}$, to w okresie od końca kwietnia 1947 do końca 1949 roku miało miejsce jedynie 46 takich rozbrojeń. Można więc stwierdzić, że doszło do załamania tego typu działalności ${ }^{78}$.

Aktywność partyzancka, choć niezmiernie uciążliwa i absorbująca znaczne siły UB i KBW, nie była już żadnym zagrożeniem dla władzy komunistycznej. Rzadkością były takie akcje jak ta z 12 lipca 1947 roku, kiedy oddział dowodzony przez por. Franciszka Majewskiego „Słonego” urządził zasadzkę na ponad czterdziestoosobową grupę operacyjną UB-MO-ORMO pod Okalewem w powiecie Rypin. W trakcie walki poległo wówczas aż 16 funkcjonariuszy resortu ${ }^{79}$. Podobnie zasadzka oddziału por. Zygmunta Jezierskiego „Orła” (Rejon NSZ Mrozy), który 1 kwietnia 1948 roku zorganizował ją koło Trzebuczy, powiat Węgrów, na konwój UB-KBW z Węgrowa przewożący czterech ujętych członków siatki 6. Wileńskiej Brygady AK do Warszawy. Rozbrojono 12 funkcjonariuszy UB i żołnierzy KBW. Dzięki akcji aresztanci zostali uwolnieni. Spośród rozbrojonych wyłowiono oficera śledczego i podoficera $\mathrm{z}$ węgrowskiego Powiatowego Urzędu Bezpieczeństwa Publicznego (PUBP), których rozstrzelano ${ }^{80}$.

Oddziały podziemia $\mathrm{w}$ wielu przypadkach odgrywały rolę sił porządkowych, wymierzając kary pospolitym przestępcom czy rozsądzając różnego rodzaju spory międzysąsiedzkie ${ }^{81}$, przy czym w niewielu przypadkach stanowiło to asumpt do prywatnych porachunków, w których wykorzystywano partyzantów. $\mathrm{W}$ rejonie swego działania oddziały zbrojne stanowiły pewne zagrożenie dla funkcjonariuszy UB, nadgorliwych milicjantów, członków PPR/PZPR (Polskiej Zjednoczonej Partii Robotniczej) czy osób podejrzewanych o tajną współpracę z UB. To te kategorie osób stanowiły zdecydowaną większość ofiar śmiertelnych

77 S. Poleszak, R. Wnuk, op. cit., s. XXXIX.

78 Atlas..., s. 105, 153, 195, 261, 291, 323, 407, 491.

79 J. Pawłowicz, Stefan Bronarski.., s. 331-332.

80 M.J. Chromiński, Żotnierze Rejonu NSZ [NZW] Mrozy w walce z komunistycznym aparatem (nie)bezpieczeństwa 1945-1948, „Wyklęci. Ogólnopolski Kwartalnik poświęcony Żołnierzom Wyklętym" 2020, nr 1(17), s. 101.

81 W tym wypadu doskonałą ilustrację dotyczącą działalności oddziałów podziemia stanowią dokumenty opublikowane w tomie: Kryptonim „Orzet”. Warszawski Okręg Zjednoczenia Wojskowego... 
wojny bratobójczej w omawianym okresie (szczególnie osoby podejrzewane o współpracę z UB). Dochodziło też do akcji, które kładły się cieniem na działalności podziemia i były wykorzystywane przez propagandę komunistyczną, aby zdeprecjonować je jako całość. Jedną z nich była pacyfikacja we wsi Puchaczów w powiecie Lublin przeprowadzona z 2 na 3 lipca 1947 roku. Tej nocy partyzanci połączonych oddziałów powinowskich dowodzonych przez ppor. Stanisława Kuchciewicza „Wiktora”, w odwecie za śmierć trzech jego podkomendnych zastrzelonych kilka dni wcześniej, zabiły 21 osób cywilnych (kolejne dwie w następstwie ciężkich ran zmarły). Odwet nie ograniczył się do trzech osób podejrzewanych jako winni śmierci partyzantów ${ }^{82}$. Tego samego dnia -2 lipca 1947 roku - we wsiach Łady-Borowe i Wybrany w powiecie Łomża, oddział por. Henryka Gawkowskiego „Roli” z KP NZW „Podhale” zastrzelił osiem spokrewnionych ze sobą osób cywilnych. Był to odwet za zamordowanie rodziców „Roli” w czerwcu 1947 roku przez funkcjonariuszy UB. Wśród zabitych osób miały znajdować się te, które rzekomo miały związek ze śmiercią Gawkowskich, inne zaś podejrzewano o donosicielstwo ${ }^{83}$. Za pacyfikację Puchaczowa ppor. „Wiktor” został jedynie zdegradowany przez mjr. Hieronima Dekutowskiego „Zaporę" ${ }^{\circ 4}$. Z kolei ppor. „Rola” wraz ze swoim bratem oraz z jeszcze jednym partyzantem NZW zostali zabici z 25 na 26 października 1947 roku z wyroku organizacji za rzekomą zdradę ${ }^{85}$.

W końcowym okresie omawianego periodu (od początku lat 50.) grupy zbrojne miały skromne składy osobowe, $\mathrm{z}$ reguły kilkuosobowe, dlatego nie nastawiały się na walkę z grupami operacyjnymi sił represji, lecz głównie na przetrwanie. Wskutek terroru kurczyła się baza osób wspomagających partyzantów. Aby przeżyć, członkowie tych grup musieli dokonywać licznych akcji ekspropriacyjnych, a czasami zdobywać żywność i odzież u osób prywatnych. W związku z tym istniała możliwość kojarzenia działalności tych grup z pospolitym bandytyzmem. Było to o wiele bardziej prawdopodobne, jeżeli grupy nie

82 Zob. więcej: Z. Broński „Uskok”, op. cit., s. 239-240; E.E. Taraszkiewicz, Trzy pamiętniki, wstęp, red. i oprac. A.T. Filipek, B. Janocińska, Warszawa-Lublin 2008, s. 172; S. Poleszak, , Żotnierze wyklęci” Mazowsza i Podlasia - major Jan Tabortowski „Bruzda”, kapitan Zdzisław Broński „Uskok” [w:] Wokół legendy „Ognia”. Opór przeciw zniewoleniu Polska-Małopolska-Podhale 1945-1956, Nowy Targ 2008, s. 106-107; G. Motyka, Grupa Operacyjna „Puchaczów” - mechanizm komunistycznej pacyfikacji na przykładzie zapoznanego epizodu akcji ,Wisła 1947 roku”, „Dzieje Najnowsze” 2020, nr 1, s. 207-210.

83 J. Kułak, op. cit., s. 838-839.

84 A. Piekarz, Adam Stanisław Kuchciewicz „Iskra”, ,Wiktor”, [w:] Ostatni komendanci.., s. 239-240.

85 P. Łapiński, Rozbicie Komendy..., s. 99. 
przeprowadzały innych akcji o charakterze antykomunistycznym. Tego typu akcje często przeprowadzano u osób postrzeganych jako sympatyzujące czy współpracujące z nową władzą oraz u członków PZPR. W okresie poamnestyjnym, gdy wraz z upływającym czasem następowało załamywanie się struktur organizacyjnych i istniejące wówczas grupy zbrojne znajdowały się poza wszelką kontrolą, wiele zależało od autorytetu i „kręgosłupa moralnego” dowódcy oddziału.

\section{METODY ZWALCZANIA STRUKTUR I ODDZIAŁÓW PARTYZANCKICH}

W okresie 1947-1953 UB wykorzystywał do rozprawy z podziemiem cały wachlarz metod. Przeprowadzano m.in. zakrojone na szeroką skalę operacje wojskowe, w trakcie których używano nawet po kilka tysięcy żołnierzy KBW. Ponadto tworzono oddziały pozorowane, które podając się za grupy niepodległościowe, nawiązywały kontakt z autentycznymi oddziałami podziemia i je likwidowały. W ramach tych działań rozpracowywały zaplecze społeczne autentycznych grup zbrojnych, a dokonując akcji ocierających się o pospolity bandytyzm, nadwątlały wizerunek podziemia. Organizowano również swego rodzaju grupy zabójców złożone z byłych członków podziemia, którzy sami bądź wzmocnieni kadrowymi funkcjonariuszami UB poszukiwali łączności z nadal działającymi w podziemiu, po czym mordowali ich bądź informowali o nich stacjonujące w pobliżu jednostki KBW, które przeprowadzały końcowe operacje. Jednak najważniejszym narzędziem służącym funkcjonariuszom UB w zwalczaniu podziemia niepodległościowego była agentura. W ramach tworzonej sieci agenturalnej do pracy operacyjnej wykorzystywano informatorów, agentów i rezydentów. Do tajnej współpracy werbowano ich na różne sposoby. Używano do tego szantażu, np. straszono aresztowaniem lub wieloletnim więzieniem czy też że coś złego stanie się komuś z najbliższych. Werbowano również w oparciu o tzw. materiały kompromitujące. Czynnikiem odgrywającym ważną rolę w nakłonieniu do podjęcia działań konfidencjonalnych były środki finansowe. Ostatnim bodźcem, który wykorzystywano, były „uczucia patriotyczne” (używanie argumentacji, która skłaniała do dobrowolnego podjęcia współpracy) ${ }^{86}$. Niezwykle pomocna w wyszukiwaniu i typowaniu kandydatów do werbunku była wiedza zgromadzona W oświadczeniach ujawnieniowych z wiosny 1947 roku.

86 Wskazówki do pracy operacyjnej przeciw podziemiu. Z materiałów szkoleniowych MBP, do druku podali K. Krajewski, T. Łabuszewski, wstęp i przypisy F. Musiał, „Zeszyty Historyczne WiN-u” 2009, nr 30, s. 222 i n. 
Największą prowokacją w omawianym okresie, którą funkcjonariusze MBP przeprowadzili pod nadzorem sowieckiego MGB (Ministerstwo Gosudarstwiennoj Biezopasnosti), była operacja ukryta pod kryptonimem „Cezary”. Rozpoczęto ją po aresztowaniu członków IV ZG WiN na czele z ppłk. Łukaszem Cieplińskim. Oficerom operacyjnym MBP udało się zwerbować kierownika Biura Studiów w Wydziale Informacji IV Zarządu WiN - Stefana Sieńkę „Wiktora”. Posiadał on olbrzymią wiedzę na temat funkcjonowania organizacji. Co więcej, był spokrewniony z szefem Delegatury Zagranicznej WiN kryptonim „Dardanele” ppłk. Józefem Maciołkiem, który darzył „Wiktora” bardzo dużym zaufaniem. Stworzono fikcyjną tzw. V Komendę WiN, w skład której weszli tajni współpracownicy UB oraz kadrowi oficerowie MBP. Bardzo ważną rolę, szczególnie na początku operacji, odegrał wspomniany wcześniej Sieńko, który uwierzytelnił nowe dowództwo organizacji, biorąc udział w spotkaniu z kurierami przybywającymi do kraju, a pośrednio przed Delegaturą Zagraniczną WiN. Podstawowym celem operacji było przejęcie kontroli nad wciąż działającym w Polsce podziemiem, zinfiltrowanie Delegatury Zagranicznej WiN oraz podjęcie gry dezinformacyjnej wobec wywiadów państw anglosaskich. Operacja trwała od wiosny 1948 roku do grudnia 1952 roku. W pierwszej fazie (lato 1948 - późna jesień 1950) rozgrywkę prowadzono głównie z Delegaturą Zagraniczną WiN. Rozpoznawano się w sytuacji, jaka panowała na emigracji, przyjmowano kurierów, którzy docierali do kraju, a także budowano wiarygodność organizacji jako ruchu autentycznie niepodległościowego. Do organizacji zaczęto też wciągać osoby, które chciały prowadzić działalność antykomunistyczną w podziemiu krajowym. W drugim okresie (listopad 1950 - listopad 1951) główne ostrze działań skierowano wobec Delegatury Zagranicznej. Wiązało się to z podpisaniem przez Delegaturę porozumienia z wywiadem USA. W trakcie ostatniego etapu (grudzień 1951 - grudzień 1952) próbowano uporządkować różne wątki operacji oraz podjęto starania mające na celu rozbudowę organizacji krajowej.

W czasie trwania prowokacji przejmowano przerzucanych z Zachodu agentów. Z kraju wysyłano emisariuszy ze sfabrykowanymi sprawozdaniami o sytuacji w kraju i o rzekomej konspiracji. Na Zachód docierały też osoby, które przechodziły tam przeszkolenie dywersyjne i wywiadowcze. V Komenda WiN utrzymywała z CIA i SIS łączność radiową. Otrzymała też od CIA „Plan Wulkan”. Był to wykaz węzłów komunikacyjnych i głównych fabryk w Polsce, które miały zostać zniszczone przez komórki WiN na wypadek wybuchu trzeciej wojny światowej. Za pośrednictwem prowokacyjnej komendy MBP weszło też w posiadanie założeń „Planu X”, czyli działań, które miało podjąć podziemie bezpośrednio przed wybuchem wojny oraz w czasie jej trwania. Dla MBP cenne informacje przesyłały również delegatury zagraniczne WiN. 
Operację przerwano dość niespodziewanie w grudniu 1952 roku, a publiczna informacja o ,ujawnieniu się" V Komendy WiN ukazała się 28 grudnia 1952 roku. W czasie jej trwania UB przejął kilkanaście przesłanych z Zachodu radiostacji i ponad milion dolarów. Represjami objęto łącznie około 300 osób. Do sierpnia 1953 roku aresztowano 116 działaczy WiN (inne dane wskazują, że było ich 139). Przez cały czas byli oni przekonani, że służą w autentycznej organizacji niepodległościowej. Sądy wojskowe skazały 55 osób, w tym 11 na karę śmierci. Na przestrzeni kilku lat wywiad komunistycznej Polski z sowieckim nadzorem prowadził grę z wywiadami anglosaskimi oraz z częścią środowisk polskiej emigracji. Pozyskaną w ramach operacji wiedzę, dokumenty oraz fakt „ujawnienia się” prowokacyjnej komendy wykorzystano na początku 1953 roku w wielkiej kampanii propagandowej demaskującej ,imperialistów amerykańskich”, „reakcyjną emigrację” oraz resztki podziemia w kraju. Efekty operacji osiągnięte w kraju były mizerne, jeśli zestawi się je z nakładami sił i środków, które w nią zaangażowano. Wyniki operacji były poważnym argumentem świadczącym o tym, że w tym czasie nie było na terenie Polski zorganizowanego podziemia, w co nie wierzono w MBP ${ }^{87}$.

„Ujawnienie się" V Komendy WiN, a raczej zakończenie prowokacji, wywołało tzw. aferę Bergu, która nazwę wzięła od podmonachijskiej miejscowości, gdzie znajdowała się jedna z baz łączności utworzona po podpisaniu umowy o współpracy między Radą Polityczną (Stronnictwo Narodowe, PPS, PRW „NiD”) a wywiadem amerykańskim (CIA) i brytyjskim (SIS). Ujawnienie tego faktu przez komunistów wywołało rozłam w środowiskach emigracyjnych. Potępił go ówczesny prezydent na uchodźstwie August Zaleski oraz m.in. liczne grono byłych oficerów AK i Narodowej Organizacji Wojskowej ${ }^{88}$.

Ofiarą prowokacji „Cezary” stał się też jeden z najważniejszych dowódców partyzanckich powojennego podziemia w Polsce - kpt. Kazimierz Kamieński „Huzar”, ostatni dowódca 6. Wileńskiej Brygady AK, operującej na terenie południowego Podlasia. Jesienią 1951 roku jednemu z tajnych współpracowników UB o kryptonimie „Rytel” (Janusz Terlikowski, były żołnierz AK) udało się dotrzeć bezpośrednio do „Huzara”. W dalszej części kombinacji operacyjnej wprowadzano kolejnych agentów MBP. Byli to przeważnie zasłużeni działacze

87 Zob. więcej: W. Frazik, Operacja ,Cezary”- przegląd watków krajowych [w:] „Zwyczajny” resort. Studia o aparacie bezpieczeństwa 1944-1956, red. K. Krajewski, T. Łabuszewski, Warszawa 2005, s. 400-436; Operacja ,Cezary”- ubecka analiza gry z WiN-em, przypisami opatrzył W. Frazik, „Zeszyty Historyczne WiN-u”, 2001, nr 15, s. 183-255; P. Lipiński, Kroków siedem do końca. Ubecka operacja, która zniszczyła podziemie, Wołowiec 2020.

${ }^{88}$ R. Wnuk, Dwie prowokacje - piata komenda Zrzeszenia , WiN” $i$ Berg, „Zeszyty Historyczne" 2002, z. 141, s. 71-112; S. Łukasiewicz, op. cit., s. 606 i n. 
niepodległościowi, tym bardziej niebezpieczni, gdyż znali realia podziemia, mentalność, sposób myślenia i obowiązujące sposoby zachowania. W trakcie kolejnych spotkań agenci występujący w charakterze przedstawicieli centralnej organizacji WiN domagali się od kpt. „Huzara” zaprzestania dokonywania jakichkolwiek akcji zbrojnych, umieszczenia ludzi na bezpiecznych kwaterach i skupienia się na pracy organizacyjnej, czyli budowie organizacji opartej na sformalizowanej strukturze. Na początku 1952 roku kpt. Kamieński otrzymał nominację na fikcyjnego komendanta Okręgu Białostockiego WiN. Zgodnie z zaleceniami przedstawicieli rzekomej komendy obszaru utworzył strukturę okręgową oraz szkieletową komendę okręgu, którą tworzyli autentyczni działacze niepodległościowi. W trakcie operacji funkcjonariusze MBP rozpoznali siatkę konspiracyjną oddziału „Huzara”. Równocześnie prowadzono intensywne działania wojskowe skierowane przeciwko patrolom partyzanckim 6. Wileńskiej Brygady AK, które były systematycznie rozbijane. Beznadziejna sytuacja skłoniła kpt. „Huzara” do skorzystania z ,pomocy” rzekomej komendy obszaru i wyjazdu do Warszawy, dokąd dotarł 17 października 1952 roku, a 10 dni później został ujęty w sfingowanej akcji ${ }^{89}$.

W oparciu o podobną „legendę”, choć niezwiązaną z V Komendą WiN, nawiązano łączność z oddziałem chor. Adama Kusza „Adama”, który operował na pograniczu rzeszowsko-lubelskim. Dowódca nie chciał podjąć ryzyka przerzutu na „bezpieczny” teren, wobec czego przydzielono mu do ochrony radiostację wraz z dwuosobową obsługą. W czasie pobytu w Lasach Janowskich radziści nadawali rzekome meldunki, a w rzeczywistości podawali koordynaty oraz szczegółowe informacje dotyczące oddziału partyzanckiego. Ostatecznie w dniach 19-22 sierpnia 1950 roku uruchomiono operację wojskową, w której użyto prawie 2 tys. żołnierzy KBW. Oddział Kusza został rozbity i stracił kilku partyzantów, w tym dowódcę, którzy zginęli w trakcie walki ${ }^{90}$. W 1951 roku, używając „legendy” o organizacji centralnej, do Warszawy zwabiono dowódcę kilkuosobowej grypy przetrwania działającej na terenie powiatu lubartowskiego

89 Zob. więcej: T. Łabuszewski, Kryptonim „,Obszar”-,,Narew”. Rozgrywka Ministerstwa Bezpieczeństwa Publicznego przeciwko konspiracji kpt. Kazimierza Kamieńskiego „Huzara”, [w:] „Zwyczajny” resort..., s. 376-399. Zob. także: K. Krajewski, Działania operacyjne Wojewódzkiego Urzędu Bezpieczeństwa Publicznego w Warszawie przeciwko oddziałom kpt. Kazimierza Kamieńskiego „Huzara” w latach 1949-1952, [w:] ,Zwyczajny” resort..., s. 343-375.

90 A.G. Kister, Rozbicie oddziału partyzanckiego Adama Kusza 19 sierpnia 1950 roku, „Niepodległość. Czasopismo Poświęcone Najnowszym Dziejom Polski” 2005, t. 55, s. 348-363; S. Poleszak, Działalność tajnych współpracowników, braci Wacława i Tadeusza Topolskich w świetle dokumentów UB, [w:] Od zniewolenia do wolności. Studia historyczne, red. A.F. Baran, WarszawaBiałystok 2009, s. 226-233. 
- Mariana Strzeleckiego „Borysa”. Po dokładnym opisaniu sposobu działalności oddziału i jego siatki współpracowników został on formalnie zatrzymany. Ujęto też jego trzech podkomendnych, którzy przebywali na terenie powiatu lubartowskiego. Co ciekawe, w prowokacji wykorzystano jednego z agentów, który brał udział w prowokacji zorganizowanej przeciwko kpt. Kamieńskiemu „Huzarowi”. Chodzi o Mariana Obniskiego, byłego działacza SN, żołnierza AK Okręgu Lublin i działacza WiN na Pomorzu ${ }^{91}$. W czerwcu 1952 roku, w wyniku podobnej kombinacji operacyjnej, do wyjazdu z Suwalszczyzny nakłoniono dowódców grupy „przetrwaniowej” - Eugeniusza Gołębiowskiego „Gabrysia” i Edmunda Krysiuka „Lota”. Oni również przez kilka miesięcy przebywali w Warszawie. W październiku 1952 roku łączność z grupą na Suwalszczyźnie zerwano, a w grudniu 1952 roku obaj zostali aresztowani i przekazani pionowi śledczemu $\mathrm{MBP}^{92}$.

Jednak dominującą formą w działaniach podejmowanych przeciwko oddziałom podziemia było operowanie grupami operacyjnymi (w sile plutonu, kompanii lub batalionu) KBW. Wobec słabych wyników osiągniętych w pierwszym kwartale 1948 roku Departament III MBP w porozumieniu ze sztabem KBW opracował plan operacji obejmującej styk trzech województw: warszawskiego, białostockiego i lubelskiego. $\mathrm{Z}$ różnym natężeniem trwała ona od 20 kwietnia do połowy sierpnia 1948 roku. Do jej przeprowadzenia zaangażowano ponad 1500 żołnierzy KBW i około 200 funkcjonariuszy UB i MO. Nadano jej kryptonim ,Z”. W trakcie jej trwania największe straty poniosła 6. Wileńska Brygada AK, rozbiciu uległy bowiem jej dwa szwadrony, a śmierć ponieśli dowódcy: 7 maja 1948 roku pod Ogrodnikami w powiecie Sokołów Podlaski poległ ppor. Antoni Borowik „Lech”, a 3 lipca tego roku we wsi Krawce w powiecie Siedlce zginął ppor. Walerian Nowacki „Bartosz"93.

Jeszcze w trakcie trwania operacji „Z” uruchomiono drugą długofalową operację o kryptonimie „P”. Jej obszarem objęto pogranicze województw: warszawskiego, olsztyńskiego i białostockiego. Działania prowadzono od 19 maja do 15 sierpnia 1948 roku. W pierwszej fazie jej trwania użyto 2600 żołnierzy $\mathrm{KBW}$, tworząc $\mathrm{z}$ nich pięć grup operacyjnych w sile batalionu. Głównym celem

91 S. Poleszak, Zwalczanie oddziałów podziemia niepodległościowego przez UB po 1947 r. przy użyciu ,legendy” o organizacji centralnej, https://przystanekhistoria.pl/pa2/teksty/79337,Zwalczanie-oddzialow-podziemia-niepodleglosciowego-przez-UB-po-1947-r-przy-uzyci.html [dostęp: 20.04.2021].

92 B. Rychlewski, Antoni Kwidorowicz (Antanas Kvedaravičius) „,Lis”, „, Stryjek”, [w:] Ostatni komendanci..., s. 136.

93 M. Jaworski, Korpus Bezpieczeństwa Wewnętrznego 1945-1965, Warszawa 1984, s. 145146; K. Krajewski, T. Łabuszewski, „Łupaszka”, „,Młot”, „,Huzar”..., s. 750-751, 737-739. 
była Komenda Okręgu NZW „Orzeł” i podległe jej oddziały zbrojne ${ }^{94}$. W dniu 25 czerwca 1948 roku dzięki donosowi agenta UB zlokalizowano położenie bazy partyzanckiej między wsiami Kierzek i Gleba w gminie Kadzidło w powiecie ostrołęckim. W bazie przebywał sztab por. Kozłowskiego „Wisa” i partyzanci z ochrony, w sumie 15 ludzi. Do zdobycia bazy użyto ponad 1500 żołnierzy KBW, wyposażonych w broń ciężką. Operację wspomagały samoloty. W wyniku kilkugodzinnej walki 4 partyzantów poległo, a 11 dostało się do niewoli (komendant, jego zastępca, szef sztabu oraz szef propagandy i wywiadu) ${ }^{95}$. W trakcie dziewięćdziesięciodniowej operacji zabito 17 członków podziemia, 7 raniono, ujęto 102 partyzantów i członków organizacji, 273 współpracowników podziemia i 398 osób podejrzanych o współpracę z nim ${ }^{96}$. Należy podkreślić, że działania grup operacyjnych UB-KBW miały nie tylko doprowadzić do rozbicia czy likwidacji oddziałów zbrojnych, lecz także do zastraszenia miejscowej ludności, aby zniechęcić ją do wspomagania partyzantów. W trakcie tych operacji przeprowadzano brutalne rewizje polegające na niszczeniu całego dobytku osób podejrzewanych o sprzyjanie „leśnym”97. Warto wskazać, że za sam fakt niepowiadomienia odpowiednich władz o tym, że posiadało się wiedzę o miejscu pobytu „leśnych” (czyli tzw. paragraf „wiedział nie powiedział”), groziła kara do 5 lat więzienia. W takich przypadkach orzekano też karę dodatkową, czyli przepadek całego majątku. Oznaczało to całkowitą ruinę majątkową danej rodziny.

W tydzień po rozbiciu komendy Okręgu „Orzeł” - 1 lipca 1948 roku - we wsi Dąbrowa-Tworki w powiecie Wysokie Mazowieckie grupa pozorowana UB-KBW, podająca się za oddział podziemia, w następstwie działań agenta „Karpińskiego" (były partyzant 6. Wileńskiej Brygady AK) nawiązała kontakt z komendantem Okręgu NZW Białystok ppłk. Władysławem Żwańskim „Błękitem” i jego ochroną. W wyniku strzelaniny „Błękit” zginą ${ }^{98}$.

Operacje MBP uderzały w wybrane środowiska, które komunistyczna władza uważała za wrogie. W miesiącach letnich 1948 roku w ramach „Akcji X” podjęto szeroko zakrojone działania skierowane przeciwko działaczom niepodległościowym ze środowiska wileńskiego. Niemal na samym jej początku, bo 26 czerwca, we Wrocławiu funkcjonariusze UB aresztowali komendanta okręgu

94 M. Jaworski, op. cit., s. 146-147.

95 K. Krajewski, Podziemie niepodległościowe..., s. 131-132; K. Kacprzak, op. cit., s. 252-253; K. Krajewski, Działania WUBP w Warszawie przeciwko podziemiu zbrojnemu w latach 1945-1954, [w:] Pion walki z podziemiem niepodległościowym RBP/MBP 1944-1954, red. T. Ruzikowski, Warszawa 2016, s. 345-346.

96 M. Jaworski, op. cit., s. 148.

97 Z. Broński „Uskok”, op. cit., s. 270 i n.

98 P. Łapiński, Władysław Żwański..., s. 630-631. 
- ppłk. Antoniego Olechnowicza „Pohoreckiego”. Na przestrzeni kolejnych tygodni doprowadzono do zatrzymania najważniejszych oficerów komendy. Tym samym w połowie sierpnia 1948 roku funkcjonariusze UB mogli stwierdzić, że doprowadzili do całkowitego rozbicia sztabu Eksterytorialnego Okręgu Wileńskiego AK i jego siatki. Piotr Niwiński obliczył, że w ramach wspomnianej „Akcji X” (aresztowania trwały jeszcze w kwietniu 1949 roku) zatrzymano i poddano sankcji prokuratorskiej 6 tys. osób ${ }^{99}$. Wśród zatrzymanych liczną grupę stanowiły osoby należące do środowiska wileńskiego, ale niezaangażowane wówczas w żadną działalność konspiracyjną. Od tego czasu partyzanci 6. Brygady Wileńskiej AK działali samodzielnie.

Przeprowadzano też operacje z wykorzystaniem tzw. agentów wewnętrznych. Jesienią 1948 roku funkcjonariusze Wydziału III WUBP w Warszawie sformowali początkowo doraźny zespół „likwidacyjny”, złożony z byłych funkcyjnych partyzantów XVI Okręgu NZW (Henryk Skonieczny „Roman”, Wacław Mówiński „Szczygieł”). Przyczynili się oni do aresztowania dziesiątków konspiratorów i osób wspomagających podziemie, wydali miejsca usytuowania magazynów broni oraz - co najistotniejsze - zamordowali dwóch swoich niedawnych towarzyszy broni, którzy na teren powiatu ostrołęckiego przybyli w 1944 roku z Wileńszczyzny. Wiosną 1949 roku kolejnych dwóch partyzantów Okręgu „Orzeł” (Zygmunt Pierzchała „Janek” i Marian Gadziński „Janek”) za cenę ocalenia życia zamordowali swojego dowódcę, komendanta Powiatu NZW „Podlasie”, Henryka Białczaka „Waldemara”. Zachęcające wyniki tego typu operacji skłoniły funkcjonariuszy wspomnianego Wydziału do utworzenia w lipcu 1949 roku swoistego komanda śmierci złożonego z partyzantów NZW (Stefan Kochański „Mewa”, Marian Majkowski „Sowa”, Stanisław Wnuk „Szczupak”, Stanisław Majkowski „Skromny” - dwaj pierwsi to byli komendanci powiatowi NZW), którzy za cenę szansy wyjścia z beznadziejnego położenia zdecydowali się na skrytobójcze mordowanie swoich towarzyszy broni. Występowali jako autentyczny patrol partyzancki. Funkcjonariusze UB nadali im kryptonim „V Kolumna”. W dniu 19 sierpnia 1949 roku pod wsią Amelin koło Krasnosielca w powiecie makowskim zamordowali komendanta Okręgu XVI „Tęcza” chor. Witolda Boruckiego „Babinicza”, jego adiutanta i komendanta powiatu „Błękit” Stanisława Suchołbiaka „Szarego”. Aby chronić prawdziwych sprawców, zaaranżowano obławę i walkę oddziału KBW, w której mieli polec zamordowani. W październiku 1949 roku członkowie „V Kolumny” „wystawili” grupie operacyjnej KBW patrol dowodzony przez st. sierż. Eugeniusza

99 Szerzej na ten temat: P. Niwiński, Działania komunistycznego aparatu represji wobec środowisk kombatantów wileńskiej AK 1945-1980, Warszawa 2009, s. 69 i n., 117-118, 123-125. 
Lipińskiego „Mrówkę”, w wyniku czego 15 października w Olszewce koło Jednorożca w powiecie Przasnysz pięcioosobowy patrol „Mrówki” uległ zagładzie. Członkowie „V Kolumny” zostali zabici przez swoich mocodawców podczas spotkania, do którego doszło prawdopodobnie 3 lipca 1950 roku w lesie koło Przasnysza. Całą operację starannie zakamuflowano ${ }^{100}$. Podobna grupa działała w latach 1949-1950 na Białostocczyźnie. Jej główną postacią był były członek AK-WiN Wacław Snarski „Księżyc”. W styczniu 1950 roku wprowadził w zasadzkę trzech partyzantów z grupy Gabriela Oszczapińskiego „Dzięcioła”, którzy zostali zabici przez grupę operacyjną UB-KBW. Następnie w zasadzkę wprowadził dowódcę oddziału, którego ujęto. W operacji wymierzonej przeciwko grupie Czesława Czyża „Dzika” agenta wspomagało dwóch kadrowych pracowników UB, udających partyzantów. W dniu 15 sierpnia 1950 roku podczas postoju poczęstowali pięcioosobową grupę „Dzika” wódką zawierającą środki nasenne, po czym do akcji wkroczyła grupa operacyjna UB-KBW, zabijając czterech partyzantów i obezwładniając dowódcę. Następnie postanowiono utworzyć stałą grupę likwidacyjną, w której oprócz „Księżyca” znalazł się sierż. Szymon Urban, były komendant ochrony PUBP w Sokółce i N.N. „Zemsta”. Grupa zastosowała podobny scenariusz wobec kolejnego oddziału dowodzonego przez Franciszka Kisielewskiego „Sosnę”. Podczas postoju, prawdopodobnie po poczęstowaniu wódką ze środkami nasennymi, agent sam zastrzelił 4 partyzantów. W sumie „Księżyc" i jego pomocnicy przyczynili się do śmierci 14 partyzantów (12 zginęło w trakcie operacji, 2 ujętych stracono na mocy wyroku Wojskowego Sądu Rejonowego w Białymstoku). „Księżyc” i sierż. Urban zostali zabici w listopadzie 1950 roku przez ukrywających się wśród bagien nad biebrzańskich mjr. Jana Tabortowskiego „Bruzdę” i kpt. Stanisława Cieślewskiego „Lipca”. Mieli być kolejnym celem, ale rozszyfrowali prowokatorów ${ }^{101}$.

Główna metoda zwalczania struktur i oddziałów podziemia niepodległościowego opierała się jednak na pracy operacyjnej z siecią agenturalną i na działaniach grup operacyjnych UB i KBW. Oddziały i grupy zbrojne, wykazane w Atlasie polskiego podziemia niepodległościowego 1944-1956, były przez grupy operacyjne UB i KBW w kolejnych latach systematycznie rozbijane i likwidowane: w 1947 roku rozbito ich 16, w następnym roku - 26, a w 1949 roku - 27. Na przestrzeni następnych lat było to to odpowiednio: w 1950 roku

${ }^{100}$ K. Krajewski, T. Łabuszewski, Zamordowani mordercy.., s. 192-195; K. Kacprzak, op. cit., s. 290-291; K. Krajewski, T. Łabuszewski, Witold Borucki..., s. 64-65.

${ }^{101}$ P. Łapiński, S. Poleszak, Posłańcy śmierci. Kombinacje operacyjne aparatu bezpieczeństwa na Białostocczyźnie 1949-1950, „Pamięć i Sprawiedliwość” 2003, nr 1(3), s. 135, 138-139, 141$143,144,151-152$. 
- 15, w 1951 roku - 12, w 1952 roku - 17, w 1953 roku - 7. Z danych KBW wynika, że największe straty osobowe po amnestii 1947 roku podziemie poniosło w latach 1947 i 1948, odpowiednio 2149 i 306, natomiast w kolejnych latach było to odpowiednio: w 1949 roku - 98, w 1950 roku - 69, w 1951 roku - 49, w 1952 roku - 54, w 1953 roku - 17. W sumie daje to 2742 zabitych. W okresie 1947-1953 aresztowano 12757 osób, które zakwalifikowano jako członków podziemia. Z tej liczby tylko w 1947 roku ujęto 9608 osób. W tym samym przedziale czasowym aresztowano w sumie 34576 osób, które uznano za współpracujące $\mathrm{z}$ podziemiem lub podejrzane o taką współpracę ${ }^{102}$.

\section{PODSUMOWANIE}

Akcja ujawnienia przeprowadzona wiosną 1947 roku stała się cezurą niezmiernie ważną w dziejach polskiej konspiracji niepodległościowej. Przeprowadzając ją, władze komunistyczne w Polsce złamały ostatecznie „kręgosłup” podziemia. Co prawda, część struktur konspiracyjnych i oddziałów partyzanckich postanowiła kontynuować opór wobec postępującej sowietyzacji kraju, jednak dla władzy nie były one już groźnym przeciwnikiem, a raczej uciążliwym brzemieniem, którego ostatecznie należało się pozbyć. Świadomość tego, że ich walka może być skazana na porażkę, mieli sami działacze niepodległościowi. Dlatego tak silne było przekonanie o nieuchronności wybuchu trzeciej wojny światowej, w której upatrywano szansy na zmianę porządku światowego i odzyskanie przez Polskę niepodległości. Z przywołanych szacunkowych danych wynika, że przez oddziały i grupy zbrojne przeszło w tym okresie od ponad 1200 do niemal 1900 partyzantów. Jednak niezmiernie trudno oszacować liczbę osób, które działały w strukturach organizacji podziemnych. Zapewne można mówić o kilku tysiącach osób. Warto też wspomnieć o tych, którzy - nie będąc już członkami żadnej organizacji - stanowili zaplecze aprowizacyjno-kwaterunkowo-wywiadowcze dla operujących oddziałów partyzanckich i grup zbrojnych.

Amnestia z wiosny 1947 roku nie zmieniła dotychczasowej mapy oporu. W dalszym ciągu najbardziej intensywny był on na obszarze trzech województw: białostockiego, lubelskiego oraz w północnej i wschodniej części warszawskiego.

W dziejach podziemia niepodległościowego działającego w okresie 19471953 można wyznaczyć dwa podstawowe okresy. Pierwszy z nich obejmuje czas od zakończenia akcji ujawnienia w kwietniu 1947 roku do przełomu lat 1949/1950, kiedy to rozbito ostatnie organizacje mające zorganizowane struktury.

\footnotetext{
${ }^{102}$ M. Jaworski, op. cit., s. 283, 288. W 1954 roku miało zginąć 15 osób związanych z podziemiem, a w 1955 roku -4 .
} 
Ramy chronologiczne kolejnego periodu obejmują czas od początku 1950 roku do 1953 roku. Rozbito wówczas ostatnie grupy lokalne oraz działające samodzielnie oddziały zbrojne. Po 1953 roku pozostało co najwyżej kilkanaście typowych, kilkuosobowych grup ,przetrwaniowych”. W okresie 1948-1952 MBP pod kontrolą sowieckiego MGB przeprowadziło największą prowokację wymierzoną m.in. w powojenne podziemie, czyli operację „Cezary”.

Działające w analizowanym okresie organizacje podziemne i oddziały partyzanckie były obiektem szczególnego zainteresowania komunistycznej policji politycznej. Zapoznając się z dziejami poszczególnych związków podziemnych czy oddziałów partyzanckich, odkrywamy szczegóły metod operacyjnych, które funkcjonariusze UB stosowali, aby doprowadzić do rozpracowania, rozbicia, aresztowania bądź fizycznej likwidacji członków danej organizacji czy oddziału partyzanckiego.

\section{BIBLIOGRAFIA}

\section{Źródla archiwalne}

IPN BU, 0397/79, Dane liczbowe o osobach objętych amnestiami w latach 1945, 1947, 1952, Ministerstwo Spraw Wewnętrznych, Biuro „C”, Warszawa 1972.

\section{Źródła drukowane}

Aparat bezpieczeństwa w latach 1944-1956. Taktyka, strategia metody działania, cz. 1: Lata 19451947, oprac. A. Paczkowski, Warszawa 1994.

Broński Z., „Uskok”, Pamiętnik (wrzesień 1939 - maj 1949), wstęp i red. S. Poleszak, Lublin-Warszawa 2015.

„Dardanele”. Delegatura WiN-u za granica (1946-1949), wstęp, dobór tekstów, przypisy S.J. Rostworowski, Wrocław 2000.

Informator o nielegalnych antypaństwowych organizacjach $i$ bandach zbrojnych działajacych w Polsce Ludowej w latach 1944-1956, Warszawa 1964 (reprint: Lublin 1993).

Kryptonim ,,Orzet”. Warszawski Okręg Zjednoczenia Wojskowego w dokumentach 1947-1954, red. K. Krajewski, T. Łabuszewski, J. Pawłowicz, L. Żebrowski, Warszawa 2004.

Memoriat Zrzeszenia WiN do Departamentu Stanu USA z 15 czerwca 1947 r. w sprawie nawiazania wspótpracy politycznej, oprac. A. Waligóra-Zblewski, Z. Zblewski, „Zeszyty Historyczne WiN-u" 1999, nr 12.

Operacja „,Cezary”- ubecka analiza gry z WiN-em, przypisami opatrzył W. Frazik, „Zeszyty Historyczne WiN-u", 2001, nr 15.

Rozpracowanie i likwidacja Rzeszowskiego Wydziału WiN w dokumentach UB (1945-1949), wybór, wstęp i oprac. T. Balbus, Z. Nawrocki, Warszawa 2001.

Taraszkiewicz E.E., Trzy pamiętniki, wstęp, red. i oprac. A.T. Filipek, B. Janocińska, WarszawaLublin 2008.

Wskazówki do pracy operacyjnej przeciw podziemiu. Z materiatów szkoleniowych MBP, do druku podali K. Krajewski, T. Łabuszewski, wstęp i przypisy F. Musiał, „Zeszyty Historyczne WiN-u” 2009, nr 30 . 
Zrzeszenie ,, Wolność i Niezawistość” w dokumentach, luty-listopad 1947, red. J. Huchlowa, M. Huchla, t. 3, Wrocław 1997.

Zrzeszenie ,Wolność i Niezawistość” w dokumentach. Delegatura Zagraniczna WiN, red. J. Huchlowa, M. Huchla, t. 4, Wrocław 1998.

\section{Literatura}

Atlas polskiego podziemia niepodległościowego 1944-1956, red. S. Poleszak, R. Wnuk, A. Jaczyńska, M. Śladecka, Warszawa-Lublin 2020.

Balbus T., Major „Zbroja”, Wrocław 2013.

Balbus T., O Polskę Wolna i Niezawisła (1945-1948). WiN w południowo-zachodniej Polsce (geneza - struktury - działalność - likwidacja-represje), Kraków-Wrocław 2004.

Balbus T., Zrzeszenie WiN na Dolnym i Górnym Ślasku (struktury okręgowe), „Zeszyty Historyczne WiN-u" 2002, nr 17.

Bechta M., Muszyński W.J., Przeciwko pax sovietica. Narodowe Zjednoczenie Wojskowe i struktury polityczne ruchu narodowego wobec reżimu komunistycznego 1944-1956, Warszawa 2017.

Brenda W., Okręg „,Orzet” NZW na pótnocnym Mazowszu i jego kontynuatorzy, [w:] Ostatni leśni, red. T. Łabuszewski, Warszawa 2003.

Chromiński M.J., Żotnierze Rejonu NSZ [NZW] Mrozy w walce z komunistycznym aparatem (nie) bezpieczeństwa 1945-1948, „Wyklęci. Ogólnopolski Kwartalnik poświęcony Żołnierzom Wyklętym" 2020, nr 1(17).

Dziuba A., Podziemie poakowskie w województwie śląsko-dąbrowskim w latach 1945-1947, Kraków 2005.

Frazik W., Operacja „Cezary” - przegląd wątków krajowych [w:] „Zwyczajny” resort. Studia o aparacie bezpieczeństwa 1944-1956, red. K. Krajewski, T. Łabuszewski, Warszawa 2005.

Frazik W., Siatki wywiadowcze Obszaru Poludniowego Zrzeszenia „Wolność i Niezawisłość”, [w:] W sieci. Powojenne polskie siatki wywiadowcze (AK-NIE-DSZ-WiN, PSZ) w latach 19441955, red. M. Bechta, Warszawa 2016.

Gasztold-Seń P., Problemy Ministerstwa Bezpieczeństwa Publicznego w przygotowaniu i realizacji amnestii 1945 i 1947 r., [w:] Komunistyczne amnestie lat 1945-1947-drogi do ,legalizacji” czy zagłady? red. W.J. Muszyński, Warszawa 2012.

Hanus W., Jeden z ostatnich. Stefan Kobos ,,Wrzos” (1900-1976). Przyczynek do dziejów konspiracji na Narolszczyźnie, Rzeszów 2019.

Jasiak K., Działalność partyzancka Konspiracyjnego Wojska Polskiego. Z dziejów II konspiracji $w$ środkowej Polsce w latach 1945-1955, Wieluń-Opole 2008.

Jasiak K., Jan Małolepszy (1906-1949), [w:] Stownik biograficzny, t. 3: Konspiracja i opór społeczny w Polsce 1944-1956, red. T. Balbus, Kraków-Warszawa-Wrocław 2007.

Jaworski M., Korpus Bezpieczeństwa Wewnętrznego 1945-1965, Warszawa 1984.

Juszkiewicz R., Walka Niezłomnych-Wyklętych na Ziemi Mławskiej w latach 1945-1953, Mława 2016.

Kacprzak K., Podziemie zbrojne na Mazowszu Północnym $w$ walce $w$ systemem komunistycznym 1945-1952, Warszawa 2011.

Kister A.G., Rozbicie oddziału partyzanckiego Adama Kusza 19 sierpnia 1950 roku, „Niepodległość. Czasopismo Poświęcone Najnowszym Dziejom Polski” 2005, t. 55.

Komorowski K., Polityka i walka. Konspiracja zbrojna obozu narodowego 1939-1945, Warszawa 2001.

Krajewski K., Działania operacyjne Wojewódzkiego Urzędu Bezpieczeństwa Publicznego w Warszawie przeciwko oddziałom kpt. Kazimierza Kamieńskiego „Huzara” w latach 1949-1952, 
[w:] „Zwyczajny” resort. Studia o aparacie bezpieczeństwa 1944-1956, red. K. Krajewski, T. Łabuszewski, Warszawa 2005.

Krajewski K., Działania WUBP w Warszawie przeciwko podziemiu zbrojnemu w latach 1945-1954, [w:] Pion walki z podziemiem niepodległościowym RBP/MBP 1944-1954, red. T. Ruzikowski, Warszawa 2016.

Krajewski K., Gdy nie można złamać podziemia, należy je rozłożyć. „Dzikie” amnestie na terenie województwa warszawskiego (1945-1946), [w:] Komunistyczne amnestie lat 1945-1947 - drogi do ,legalizacji” czy zagłady, red. W.J. Muszyński, Warszawa 2012.

Krajewski K., Podziemie niepodległościowe w powiecie Ostrołęka po 1944 r., [w:] Powiat Ostrołęka. Materiały z sesji naukowej „Powiat Ostrołęka w pierwszej dekadzie rządów komunistycznych" zorganizowanej 23 października 2008 r. przez Oddział Instytutu Pamięci Narodowej w Warszawie i prezydenta Ostrołęki, t. 3: Mazowsze i Podlasie w Ogniu 1944-1956, red. K. Krajewski, Warszawa 2009.

Krajewski K., Siatki wywiadowcze Obszaru Poludniowego działajace na terenie Obszaru Centralnego Zrzeszenia WiN, [w:] W sieci. Powojenne polskie siatki wywiadowcze (AK-NIE-DSZWiN, PSZ) w latach 1944-1955, red. M. Bechta, Warszawa 2016.

Krajewski K., Łabuszewski T., Józef Kozłowski (1909-1949), [w:] Słownik biograficzny, t. 3: Konspiracja i opór społeczny w Polsce 1944-1956, red. T. Balbus, Kraków-Warszawa-Wrocław 2007.

Krajewski K., Łabuszewski T., „Łupaszka”, „Młot”, „Huzar”. Działalność 5. i 6. Brygady Wileńskiej AK (1944-1952), Warszawa 2002.

Krajewski K., Łabuszewski T., Witold Borucki „Dąb”, „Babinicz”, [w:] Zapomniani wyklęci. Sylwetki żotnierzy powojennej konspiracji antykomunistycznej, Warszawa 2019.

Krajewski K., Łabuszewski T., Zagadka śmierci Franciszka Potyrały „Oracza”, „Zeszyty Historyczne WiN-u” 2008, nr 28-29.

Krajewski K., Łabuszewski T., Zamordowani mordercy. Sprawa „,V Kolumny”-czyli zabójstwa na zlecenie, „Zeszyty Historyczne WiN-u” 2009, nr 30.

Kułak J., Powstanie i działalność Narodowego Zjednoczenia Wojskowego na terenie powiatu Łomża (Komenda Okręgu NZW Białystok) 1944-1948, [w:] Europa nieprowincjonalna. Przemiany na ziemiach wschodnich dawnej Rzeczypospolitej (Białoruś, Litwa, Łotwa, Ukraina, wschodnie pogranicze III Rzeczypospolitej Polskiej w latach 1772-1999, red. K. Jasiewicz, Warszawa 1999.

Lipiński P., Kroków siedem do końca. Ubecka operacja, która zniszczyła podziemie, Wołowiec 2020.

Litwiejko K., Franciszek Potyrała (1897-1947), [w:] Stownik biograficzny, t. 1: Konspiracja i opór społeczny w Polsce 1944-1956, red. J. Kurtyka, Kraków-Warszawa-Wrocław 2002.

Łabuszewski T., Amnestia 1945 r i Deklaracja Jana Mazurkiewicza „Radostawa”, [w:] Komunistyczne amnestie lat 1945-1947 - drogi do „legalizacji” czy zagłady, red. W.J. Muszyński, Warszawa 2012.

Łabuszewski T., Komenda Obszaru Centralnego „,Nie”-DSZ-WiN, „,31 ”, ,ZZatoka”, ,,Wista”, [w:] Obszar Centralny Zrzeszenia WiN 1945-1947, red. T. Łabuszewski, Warszawa 2018.

Łabuszewski T., Kryptonim „, Obszar”-”Narew”. Rozgrywka Ministerstwa Bezpieczeństwa Publicznego przeciwko konspiracji kpt. Kazimierza Kamieńskiego „Huzara”, [w:] „Zwyczajny” resort. Studia o aparacie bezpieczeństwa 1944-1956, red. K. Krajewski, T. Łabuszewski, Warszawa 2005.

Łapiński P., Rozbicie Komendy Powiatu NZW Łomża (wiosna 1947 - wiosna 1948). Z dziejów wywiadu NZW na Białostocczyźnie, [w:] Wywiadowcza i kontrwywiadowcza działalność podziemia narodowego w latach 1944-1956, red. L. Żebrowski, Warszawa 2019.

Łapiński P., Władysław Żwański (1896-1948), [w:] Słownik biograficzny, t. 3: Konspiracja i opór społeczny w Polsce 1944-1956, red. T. Balbus, Kraków-Warszawa-Wrocław 2007. 
Łapiński P., Poleszak S., Posłańcy śmierci. Kombinacje operacyjne aparatu bezpieczeństwa na Białostocczyźnie 1949-1950, „Pamięć i Sprawiedliwość” 2003, nr 1(3).

Łukasiewicz S., Partia w warunkach emigracji. Dylematy Polskiego Ruchu Wolnościowego „Niepodległość i Demokracja” 1945-1994, Lublin-Warszawa 2014.

Mazur M., Antykomunistycznego podziemia portret zbiorowy 1945-1956. Aspekty mentalno-psychologiczne, Warszawa-Lublin 2019.

Motyka G., Grupa Operacyjna „Puchaczów”- mechanizm komunistycznej pacyfikacji na przykładzie zapoznanego epizodu akcji ,Wisła 1947 roku”, „Dzieje Najnowsze” 2020, nr 1.

Niwiński P., Działania komunistycznego aparatu represji wobec środowisk kombatantów wileńskiej AK 1945-1980, Warszawa 2009.

Niwiński P., Okręg Wileński AK w latach 1944-1948, Warszawa 1999.

Ostasz G., Okręg Rzeszowski Zrzeszenia „,Wolność i Niezawisłość”. Model konspiracji, struktura, dzieje, Rzeszów 2006.

Pawłowicz J., Ostatni „leśni” zachodniego Mazowsza: XXIII Okręg Narodowego Zjednoczenia Wojskowego - 11 Grupa Operacyjna Narodowych Sit Zbrojnych, [w:] Ostatni leśni, red. T. Łabuszewski, Warszawa 2003.

Pawłowicz J., Stefan Bronarski (1916-1951), [w:] Stownik biograficzny, t. 2: Konspiracja i opór społeczny w Polsce 1944-1956, red. W. Frazik, Kraków-Warszawa-Wrocław 2004.

Piekarz A., Adam Stanisław Kuchciewicz „Iskra”, ,, Wiktor”, [w:] Ostatni komendanci. Ostatni żolnierze 1951-1963, red. M. Biernat, Warszawa [2016].

Pietrzak L., Amnestia 1947 roku i jej wykonanie przez organa bezpieczeństwa [w:] Podziemie zbrojne na Lubelszczyźnie wobec dwóch totalitaryzmów 1939-1956, red. S. Poleszak, A. Puławski, Warszawa 2002.

Poleszak S., Działalność tajnych wspótpracowników, braci Wacława i Tadeusza Topolskich w świetle dokumentów UB, [w:] Od zniewolenia do wolności. Studia historyczne, red. A.F. Baran, Warszawa-Białystok 2009.

Poleszak S., Podziemie antykomunistyczne w Łomżyńskiem i Grajewskiem (1944-1957), Warszawa 2004.

Poleszak S., „Żolnierze wyklęci” Mazowsza i Podlasia-major Jan Tabortowski „Bruzda”, kapitan Zdzisław Broński ,,Uskok” [w:] Wokół legendy „Ognia”. Opór przeciw zniewoleniu Polska - Małopolska - Podhale 1945-1956, Nowy Targ 2008.

Poleszak S., Wnuk R., Oddziały zbrojne polskiego podziemia niepodlegtościowego i organizacje młodzieżowe - próba ujęcia statystycznego, [w:] Atlas polskiego podziemia niepodległościowego 1944-1956, red. S. Poleszak, R. Wnuk, A. Jaczyńska, M. Śladecka, Warszawa-Lublin 2020.

Reduty bez wojny, „Karta” 1996, nr 18.

Rychlewski B., Antoni Kwidorowicz (Antanas Kvedaravičius) „Lis”, ,Stryjek”, [w:] Ostatni komendanci. Ostatni żotnierze 1951-1963, red. M. Biernat, Warszawa [2016].

Surdej M., Amnestie i akcja ujawnieniowa na Rzeszowszczyźnie w latach 1945-1956, [w:] Komunistyczne amnestie lat 1945-1947 - drogi do ,,legalizacji” czy zagłady, red. W.J. Muszyński, Warszawa 2012.

Szymaniak M., Zrzeszenie WiN w województwie gdańskim (1945-1947), [w:] Obszar Zachodni Zrzeszenia WiN 1945, red. K. Krajewski, Warszawa 2019.

Szyprowski B., II Inspektorat Zamojski Armii Krajowej 1948-1950, cz. I, „Wyklęci” 2016, nr 3.

Szyprowski B., II Inspektorat Zamojski Armii Krajowej 1948-1950, cz. II, „Wyklęci” 2016, nr 4.

Śmietanka-Kruszelnicki R., „Dzikie” amnestie na przykładzie Zwiazku Zbrojnej Konspiracji na ziemi radomskiej (sierpień-wrzesień 1946 r.) Inspiracje i konsekwencje [w:] Komunistyczne amnestie lat 1945-1947-drogi do ,, legalizacji” czy zagłady, red. W.J. Muszyński, Warszawa 2012. 
Toborek T., Stanisław Sojczyński i Konspiracyjne Wojsko Polskie, Łódź 2015.

Wnuk R., Dwie prowokacje - piata komenda Zrzeszenia „WiN” i Berg, „Zeszyty Historyczne” 2002, z. 141.

Wnuk R., Konspiracja akowska o poakowska na Zamojszczyźnie od lipca 1944 do 1956, Zamość 1993.

Wnuk R., Lubelski Okręg AK DSZ i WiN 1944-1947, Warszawa 2000.

Wołoszyn J., Stefan Kobos „,Michorowski”, ,Wrzos”, [w:] Ostatni komendanci. Ostatni żolnierze 1951-1963, red. M. Biernat, Warszawa [2016].

Wołoszyn J.W., Zapomniane ogniwo. Konspiracja młodzieżowa na ziemiach polskich 1944-56, Warszawa 2019.

Woźniczka Z., Zrzeszenie „,Wolność i Niezawistośc’” 1945-1952, Warszawa 1992.

Wójcik Z.K., Adam Lazarowicz (1902-1951), [w:] Stownik biograficzny, t. 2: Konspiracja i opór społeczny w Polsce 1944 -1956, red. W. Frazik, Kraków-Warszawa-Wrocław 2004.

Wójcik Z.K., Władysław Antoni Koba (1914-1949), [w:] Stownik biograficzny, t. 4: Konspiracja i opór społeczny w Polsce 1944-1956, red. M. Bielak, K. Krajewski, Kraków- WarszawaWrocław 2010.

Zblewski Z., IV Zarząd Główny Zrzeszenia „,Wolność i Niezawistość”, „Wyklęci. Ogólnopolski kwartalnik poświęcony Żołnierzom Wyklętym” 2018, nr 1(9).

Zblewski Z., Okręg Krakowski Zrzeszenia ,,Wolność i Niezawisłość” 1945-1948. Geneza, struktury, działalność, Kraków 2005.

Zblewski Z., Próba aktywowania Obszaru Zachodniego przez IV Zarząd WiN, [w:] Obszar Zachodni Zrzeszenia WiN 1945, red. K. Krajewski, Warszawa 2019.

\title{
Netografia
}

http://zhwin.pl/zrzeszenie-win/cztery-zg-win-u/iv-zarzad [dostęp: 4.05.2021].

Poleszak S., Zwalczanie oddziałów podziemia niepodległościowego przez UB po 1947 r. przy użyciu ,legendy” o organizacji centralnej, https://przystanekhistoria.pl/pa2/teksty/79337,Zwalczanie-oddzialow-podziemia-niepodleglosciowego-przez-UB-po-1947-r-przy-uzyci.html [dostęp: 20.04.2021].

\section{Akty prawne}

Ustawa z dnia 22 lutego 1947 r. o amnestii (Dz.U. 1947, nr 20, poz. 78).

\begin{abstract}
After the action of disclosing the structures of the Polish independence underground in the spring of 1947, those who remained underground did not pose any serious threat to the communist authorities. They decided to continue the fight, because they did not believe in communists, they did not accept the Sovietization of Poland and they hoped for a quick outbreak of the Third World War. The structures of the underground military organizations were broken up by the turn of 1949/1950. By the end of 1953, the last local groups and armed units had been liquidated. Only a few armed groups of a "survival" nature remained.
\end{abstract}

Keywords: the Polish independence underground; underground military organizations; armed units; communist authorities; underground 